Gendered Healing Votives in Roman Gaul: Representing the Body in a Colonial Context Author(s): Alena Wigodner

Source: American Journal of Archaeology, Vol. 123, No. 4 (October 2019), pp. 619-642

Published by: Archaeological Institute of America

Stable URL: https://www.jstor.org/stable/10.3764/aja.123.4.0619

JSTOR is a not-for-profit service that helps scholars, researchers, and students discover, use, and build upon a wide range of content in a trusted digital archive. We use information technology and tools to increase productivity and facilitate new forms of scholarship. For more information about JSTOR, please contact support@jstor.org.

Your use of the JSTOR archive indicates your acceptance of the Terms \& Conditions of Use, available at https://about.jstor.org/terms 


\title{
Gendered Healing Votives in Roman Gaul: Representing the Body in a Colonial Context
}

\author{
ALENA WIGODNER
}

After the annexation of Gaul into the Roman empire, a new religious practice began in the Gallic provinces: offering votive objects representing either parts of the body or the entire body at healing sanctuaries. Analysis of these votives offers a unique way to study the identities of women, especially nonelite women who are often archaeologically invisible. Representational healing votives allow for study of gendered experiences of colonialism in Roman Gaul because women and men were positioned differently with respect to the colonial power structure. This study of 1,050 published votive objects reveals gendered differences in body parts represented, materials used, and preferred artistic style. In scholarship on gendered behavior in colonial contexts, it is commonly argued that women generally acted as guardians of indigenous cultural practices while men more readily took on the culture of the colonizer. The results of the present examination suggest that, in Gallo-Roman healing religion, the opposite was true: while men more often referenced an indigenous identity in their votives, women represented themselves in a Roman manner more often. These results have significant implications for our understanding of gendered experiences of colonialism in the Roman provinces. ${ }^{1}$

\section{INTRODUCTION}

Gender ideology was inextricably intertwined with the Roman imperial project. On the broadest scale, imperial ideology reflected a gendered worldview: entire provinces were feminized in Roman thought, brought under control by the stronger, highly militarized, more masculine Roman empire. ${ }^{2}$ Further, Rome often justified imperialism by arguing for the need to civilize the barbarian ways of those living on the edges of the empire; it was popular to criticize gendered behavior that clashed with the Roman ideal as a sign of foreign barbarism. ${ }^{3}$ Understanding gendered behavior and decision making

American Journal of Archaeology Volume 123, Number 4

October 2019

Pages 619-42

DOI: $10.3764 /$ aja.123.4.0619

www.ajaonline.org

\footnotetext{
${ }^{1}$ I would like to thank Emma Blake, whose support and dedication made this study possible. I am also grateful to Alison Futrell and Lars Fogelin for their invaluable guidance. Preliminary results of this research were presented at the annual meeting of the Society for American Archaeology (Vancouver 2017), and a related study of the same material was presented at the Theoretical Roman Archaeology Conference (Edinburgh 2018). The thoughtful comments from these audiences usefully shaped my thinking. Lastly, I would like to thank Editor-in-Chief Jane B. Carter and the anonymous reviewers for the AJA for providing insightful critiques that greatly improved this paper. Any remaining oversights are my own.

${ }^{2}$ This is evident in religious syncretism, in which Roman gods married indigenous goddesses (see, e.g., Green 1995a, 124-35). The gendered nature of Roman imperial ideology was most graphically represented in art and literature depicting Roman conquest as rape (Whittaker 2004, 115-17; Lopez 2007, 138-42).

${ }^{3}$ Clavel-Lévêque (1996, 224), Ferris (2003, 1), and Lomas (2014, 487-90) provide useful overviews. Bittarello (2009, 217-28) discusses the concept as it relates to Roman reception of Etruscans, while Wyke (2002) approaches opinions of the Egyptian queen Cleopatra from this perspective. See Diod. Sic. 5.32; Amm. Marc. 15.12.1; Strabo 4.4.3 for primary sources on the subject relating to Roman Gaul.
} 
in colonial contexts should therefore be considered crucially important to studying Roman colonialism. While Roman scholars do not universally apply the postcolonial term "colonialism" to the Roman world, I adopt Dietler's definition of Roman colonialism, usefully differentiated from imperialism: while imperialism refers to the ideology of expansion that motivates conquest and domination, colonialism is the process of exerting control over the conquered and shaping their social and cultural practices as a result. ${ }^{4}$

As integral as gender may be to the study of Roman colonialism, obtaining evidence that allows for the study of gendered decision making is no easy task because it requires that the actions of women as well as men be visible archaeologically. The behavior of women is notoriously difficult to isolate in the archaeological record, especially the behavior of nonelite women, who were not written about as historical figures, did not make lasting architectural contributions to civic spaces, and were not lavishly buried. ${ }^{5}$ Men and women experienced and reacted to Roman colonial control differently; in this article, I analyze these differences as visible in Gallo-Roman representational healing votives-votive objects that represent either parts of the body or the entire body.

These votives began to be dedicated at sanctuaries as prayers for healing soon after Julius Caesar's troops prevailed over the armies of northern Gaul, placing the entire region under Roman control. Because this healing practice developed in a colonial context in Gaul, and because both men and women participated in the practice, analyzing healing votives provides a useful means by which to study Roman colonialism as a gendered experience. The expressions of identity represented by these votives were loaded with meaning and were critically intertwined with colonial power dynamics; a votive channeling indigeneity, Roman-ness, or the creolized admixture of both made a statement, whether conscious or not, about the offerer's position or desired position in colonial society.

Traditionally, scholars have assumed that women took on roles as guardians of indigenous ethnicity in colonial contexts, while men, by virtue of their need to participate in public, institutional imperial systems, readily adopted the culture of the colonizer. ${ }^{6}$ However,

\footnotetext{
${ }^{4}$ Dietler 2014, 18.

${ }^{5}$ Brumfiel 2007, 12-14.

${ }^{6}$ See Voss $(2005,471)$ and Tarble de Scaramelli $(2012,152)$
}

continued research on gender and households in colonial contexts has complicated this narrative, making clear that gendered behavior cannot be generalized in this way. This analysis of Gallo-Roman healing votives contributes to a more nuanced understanding of gendered colonial identities: through these votives, women were more likely than men to express romanized identities while men more closely clung to indigeneity in their votive representations. These results have significant implications for our understanding of gendered experiences of colonialism in the Roman provinces.

\section{STUDYING ROMAN GAUL AND THE ROMAN WEST}

Most Gallo-Roman healing votives have been found at sanctuaries in northern Gaul, a region inhabited by Celtic-speaking tribes ${ }^{7}$ that resisted Roman rule until Caesar's final victory in 51 B.C.E. This region held out far longer than the southern coastal region (Gallia Narbonensis had been a Roman province since 121 B.C.E.). The tribes of northern Gaul by no means went peacefully under Roman control. Violence between Rome and the northern tribes had begun long before Caesar's conquest, and isolated revolts continued for some time after annexation into the empire. Despite the establishment of Roman cities such as Lugdunum (modern Lyon) and Divio (modern Dijon) on the sites of Iron Age oppida, ${ }^{8}$ northern Gaul long remained largely rural and somewhat of a backwater. Recent research has advanced our understanding of colonial urban-rural dynamics in the region by asking such questions as: how did cities develop, or continue to develop, postconquest? ${ }^{9}$ How was rural development

\footnotetext{
for a history and critique of this narrative.

${ }^{7}$ The term "Celtic" as a cultural descriptor may be problematic (Dietler 2006, 2008). The people of the British Isles and the Continent most likely did not recognize a unified ethnic identity during the Iron Age, and it is often more productive to focus on regional and local diversity rather than general similarities across regions (Green 1995b, 6-7; Cunliffe 1997, 1; Dietler 2008, 197-99). However, I continue to find interpretive value in using "Celtic" to recognize broad similarities in language (Russell 1995; Mullen 2013), religious practice (Green 1986), and artistic style (Finlay 1973; Nerzic 1989; Harding 2007) across these regions.

${ }^{8}$ Woolf 1998, 112-16.

${ }^{9}$ Reddé 2015.
} 
linked to urban centers? $?^{10}$ How was Roman power exercised at the local level ? ${ }^{11}$

The complex landscape of Roman Gaul was marked by the joining of old (indigenous) and new (Roman and Gallo-Roman). This blending of old and new in Roman Gaul, and the Roman West more generally, has been framed through a range of postcolonial concepts seeking to do justice to the complexity of these processes. Understanding this complexity has required examination of the agency of the conquered, including critical engagement with Roman narratives of socalled barbarian peoples of Europe and emphasis on the role indigenous peoples played in shaping their environment under colonialism. ${ }^{12}$ Changes in culture under Roman rule have been considered through diverse theoretical frameworks such as middle ground, creolization, and entanglement. The middle ground, an area often created by trade relationships, is defined by values and cultural logics. In the middle ground, individuals from different cultures participate in continuous negotiation of differences. ${ }^{13}$ Creolization, originally a linguistic term for the blending of two languages, is considered a useful model for how cultures blend in colonial contexts. A creolization model frames the creation of Roman provincial cultures as a series of active, highly local processes. ${ }^{14}$ The concept of entanglement connotes the complexity and inseparability of relations, motives, and meanings in colonial contexts. ${ }^{15}$

These frameworks also help us understand the significance of those old ways that remained strong even in the face of colonialism. One of the most potent areas of life in which indigenous culture maintained its hold in Roman Gaul was religious worship. In northern Gaul in the Roman period, Celtic deities continued to be worshiped-sometimes at the same sanctuaries that had stood for centuries-at sites such as Essarois ${ }^{16}$ and Luxeuil-les-Bains. ${ }^{17}$ Of course, new sanctuaries, deities, and practices (including the practice of dedicating representational healing votives) were incorporated into religious life as well. Recent scholarship has sought to address the extent to which religion both was

\footnotetext{
${ }^{10}$ Trément 2013.

${ }^{11}$ Lamoine 2009.

${ }^{12}$ Wells 1999; Woolf 2011.

${ }^{13}$ Woolf 2011, 17-31; Dietler 2014, 24.

${ }^{14}$ Webster 2001, 218.

${ }^{15}$ Mata 2013; Dietler 2014; Coleman 2015.

${ }^{16}$ Green $1999,92-3$.

${ }^{17}$ Derks 1998, 198.
}

shaped by and shaped culture contact and colonialism in the Gallic and Germanic regions. ${ }^{18}$

My purpose is to connect the study of healing votives to current scholarship on gendered expressions of identity and experiences of colonialism in Roman Gaul. Some Gallo-Roman healing votives appear to have been homemade and some appear to have been specially commissioned, but many were likely purchased at sanctuaries from craftspeople producing them in bulk. Individuals certainly had a measure of choice in the votives they offered, but we cannot assume they enjoyed complete freedom of choice: very few commissioned their own expertly rendered individualized votives. Those who made their own votives were limited by available materials and by their own artistic abilities. For those who purchased pre-made votives, many likely had some variety to choose from and could pick the type, style, and form that most appealed to them, but these decisions would have been limited by availability and financial constraints. The votive each person ultimately offered, then, is the result of a complex balance between individual agency and more structural pressures. This balance was contingent on an individual's circumstances and identity in this colonial context. Gender, socioeconomic status, legal status, place of residence (urban or rural), and other aspects of identity combined to balance structure and agency in these expressions of individual identity.

These expressions of identity provide insight into how men and women experienced colonialism differently in Roman Gaul: how did gender affect this balance between structural pressure and individual choice? Of course, the term "balance" is not quite correct. It is impossible to separate what was imposed from what was chosen, because the one would not exist without the other; the colonial structure affected the decisions of individuals, while individuals in turn shaped the colonial structure through these decisions. ${ }^{19}$ Ultimately, each healing votive is the result of mutually dependent individual agency and colonial structure. Therefore, gendered differences in votives imply differences in the ways in which men and women lived within and experienced colonialism.

\footnotetext{
${ }^{18}$ Dondin-Payre and Raepsaet-Charlier 2006; Garman 2008; Van Andringa 2009; Mata 2013.

${ }^{19}$ Giddens 1984. Revell $(2008,10-15)$ and Mattingly (2011, 213-18) both apply Giddens' understanding of structure and agency as mutually constitutive to expressions of identity in Roman colonial contexts.
} 


\section{STUDYING GENDER IN COLONIAL CONTEXTS}

In colonial encounters, understandings of gender and gender roles may differ between colonizer and colonized. This was certainly the case in Roman Gaul, as evidenced by the Roman writers who described the large size, impressive strength, and ferocity of Gallic women, who were apparently known to fight alongside their husbands. ${ }^{20}$ Strabo (4.4.3) even remarked that in Gaul, gender roles were completely opposite those found in Greek or Roman society. While this is an exaggeration, archaeological evidence does reinforce the narrative that Gallic understandings of gender roles differed from Roman ones. Grave goods from Iron Age burials suggest more flexibility in gender roles in Gaul than in Rome, at least for elites: weapons and feasting paraphernalia (associated with elite power) are not uncommon in women's burials, while men's burials often include jewelry and other personal ornamentation appropriate only for women in Rome. ${ }^{21}$

Differences such as these between colonizers and colonized introduce new opportunities and challenges that differ based on gender. In the study of the Greek and Roman worlds, the topic of women's access to opportunity in colonial contexts is often approached through examination of intermarriage between locals and colonizers. ${ }^{22}$ First waves of colonizers tended to be mostly men (usually soldiers or traders), so intermarriage generally occurred between indigenous women and colonizing men. These marriages positioned women not only as cultural liaisons but also as useful political connections between colonizers and indigenous populations. As the wives of colonizing men, women could become the means for their entire indigenous families to gain formal status in colonial power structures.

\footnotetext{
${ }^{20}$ See Diod. Sic. 5.32; Amm. Marc. 15.12.1.

${ }^{21}$ Arnold 1999, 83; Evans 2004, 187-88; Pope and Ralston 2011. Redfern et al. (2017,257-61) have recently reported on a potentially intersex individual whose burial sheds light on gendered power during the transition to Roman rule in Britain.

${ }^{22}$ Glinister (2009, 119-21) usefully addresses this topic through studying women's ritual activity in the context of Roman colonization of Italy. Lewis $(1986,93)$ examines the effect of Egyptian women's marriages to Greek men in Ptolemaic Egypt on the legal and economic status of Egyptian families. Holder (1982, 50-4), Hope (1997, 256), and Pollard (2000, 152-59), among others, discuss the results of marriages between indigenous women and Roman soldiers on the Roman frontiers.
}

The implications of intermarriage have been studied in European colonization and trade in the Americas as well. Much of this research focuses on how the household practices of women preserved indigenous customs and supported creole behavior in mixed homes. ${ }^{23}$ However, women also made strategic decisions outside of the home to take advantage of opportunities created by the colonial dynamic. White explores Ojibwe women's active economic roles in the North American fur trade. ${ }^{24}$ Tarble de Scaramelli argues that, in Spanish-controlled Venezuela, indigenous women "sought to negotiate social mobility through conversion to Catholicism, commodity production for personal and economic gain, and, in some circumstances, sexual favors, concubinage, or marriage outside of their birth community."25 Especially relevant for the present study, Loren examines how the body, a site at which the colonizer's physical control acts on the colonized, is also a site uniquely useful for expressing difference. This is the case because colonizers assert superiority when they represent the colonized as barbaric in art, but colonized peoples can also express complex identities through clothing and ornamentation. ${ }^{26}$

Research on funerary monuments in the northwestern Roman provinces demonstrates how gendered representations allowed families to make strategic statements about their ethnic, cultural, and political identities. While some individuals commissioned funerary monuments before their deaths, many monuments were erected by an individual's family after death. Funerary monuments are also meant to be displayed publicly. Healing votives are more individual and more anonymous, but studies of these monuments do demonstrate how representations of individuals in the Roman provinces may inform us of gendered differences in strategic expressions of identity.

In a study of funerary monuments on Britain's Roman frontier, Hope argues that the erection of figurative tombstones was meant to connect the deceased to Roman society because figurative tombstones were an aspect of Roman, not British, material culture. ${ }^{27}$ Hope observes that in the second and third centuries

\footnotetext{
${ }^{23}$ Deagan 1983, 99-124; Rothschild 2003, 164-67; Lightfoot 2005, 26-7; Amussen and Poska 2012, 357-58; Beaudoin 2014.

${ }^{24}$ White 1999.

${ }^{25}$ Tarble de Scaramelli 2012, 139.

${ }^{26}$ Loren 2008.

${ }^{27}$ Hope 1997.
} 
C.E., when Roman control had been sufficiently established in the frontier region, figurative tombstones were most often erected not by Roman colonizers or the most Romanized Britons but by those least confident in their status in colonial society: "The tombstone becomes a symbol of their struggle for acceptance into a community into which they have not been readily embraced." ${ }^{28}$ Hope notes that during this period, women, likely often informal wives of soldiers, were more often represented than men on figurative tombstones..$^{29}$ It was women more often than men who were in need of, and therefore used, the symbol of Romanness that tombstones provided.

Carroll also describes stone funerary monuments, especially those with Latin epitaphs, as symbolic of Roman culture on the Rhine and Danube frontiers. ${ }^{30}$ Interestingly, these culturally Roman symbols were used to express information about local ethnicities, whether through epigraphic attribution of tribal affiliation or through representations of individuals wearing local ethnic dress. Notably, in these frontier regions, women were depicted more often in indigenous dress local to the region while men were more often depicted in Roman dress. Carroll suggests that this difference is indicative of different identities performed in the public sphere and the private sphere: while indigenous culture was preserved in the private sphere that women inhabited, the public sphere, the domain of men, became Romanized during colonization. ${ }^{31}$ While this interpretation pursues a women-private, men-public dichotomy that recent research has complicated, ${ }^{32}$ the evidence points to a useful truth: that women and men were represented in ways that differentially combined Roman and indigenous symbolism to make gendered statements about colonial identities.

In her study of funerary monuments in the Gallic and Germanic Roman provinces, Rothe's most crucial observation concerns the portrayal on tombstones of a Gallic Ensemble, a style of clothing that was not

\footnotetext{
${ }^{28}$ Hope 1997, 257.

${ }^{29}$ Hope 1997, 256. Until 197 C.E., Roman soldiers were not legally allowed to marry until their military service was finished. However, informal marriages were tolerated by military leadership before the law changed (Holder 1982, 50-4; Greene 2015). This precarious, extralegal position may have contributed to the status of soldiers' wives as outsiders.

${ }^{30}$ Carroll 2013.

${ }^{31}$ Carroll 2013, 571-72.

${ }^{32}$ See Voss 2005, 471.
}

Roman but was also not representative of pre-Roman indigenous style. Instead, this new style formed in the context of Roman colonialism and symbolized a panGallic identity that supplanted tribal differences in dress. The Gallic Ensemble on women's funerary monuments, Rothe believes, became the means by which a family could demonstrate its adherence to this regional identity. ${ }^{33}$ She notes that the largest monuments are more likely to depict individuals in Roman dress, suggesting that wealthier families valued Roman appearance more highly. In the Treveran region, women were in fact more often depicted in Roman dress than men were. ${ }^{34}$ Rothe's research indicates that it is insufficient to imagine a gendered binary in which representations of women express indigenous identity and representations of men express Roman identity; the reality was far more complex.

It is clear that in the Roman northwest, cultural values were gendered, and therefore men and women were represented differently on these public monuments. Gendered expressions of cultural values varied based on other aspects of identity including region and class. In contrast to funerary monuments, almost all healing votives were anonymous. ${ }^{35}$ In addition, individuals had more control over the healing votives they offered than they did over their own funerary monuments. The decision concerning what votive to offer was likely influenced by financial constraints and potentially gendered availability: when men and women chose the votives they wished to dedicate, did they have a similar variety to choose from, or did craftspeople produce different styles of votives for men than they did for women? We cannot know the answer to this question, because the votives available for men and women likely differed over time and between sanctuaries. Cultural expectations and market demand likely influenced the types of votives available, so differences in the votives men and women offered should be understood as the results of individual men's and women's choices from the potentially gendered variety of votives available on any given day.

This assumes, however, that women and men were equally responsible for choosing the votives they

\footnotetext{
${ }^{33}$ Rothe 2009, 54-8; 2012, 239-42.

${ }^{34}$ Rothe $(2012,241)$ notes that 21 of 78 men's tombstones (27\%) depict men in Roman dress while 22 of 60 women (37\%) wear Roman dress on their tombstones.

${ }^{35}$ Out of 1,050 catalogued healing votives, only seven are inscribed with names.
} 
offered. I argue below that individuals in need of healing generally traveled to sanctuaries themselves to offer votives rather than allowing a family member to do so for them. It is reasonable to assume, then, that women had the same access to vendors of votive objects that men did. In addition, textual and epigraphic evidence suggests that women had the financial independence to choose and purchase their own votives, thus we should not assume that men chose women's votives as a condition of providing the funds. While women had few political rights in Roman Gaul, they could inherit, sign wills, and own businesses. ${ }^{36}$ The wealthiest women even became benefactors of public buildings and events. ${ }^{37}$ This is not to say that men's and women's buying power was necessarily equal in Roman Gaul, but these votive objects were generally not extravagant (the vast majority are made from limestone, wood, or thin bronze sheets), and most women likely had the ability to purchase them for themselves.

\section{GALLO-ROMAN HEALING VOTIVES}

The earliest dated representational healing votives in Gaul were made ca. 40 B.C.E., about 10 years after Caesar's final successful conquest in northern Gaul, and were found at the site of Sources de la Seine near modern Dijon. ${ }^{38}$ The Gauls were not the first to practice healing religion using representational votives; similar votives were commonly offered to the god Asclepius at healing sanctuaries in Greece and the Hellenistic East and to various deities in Italy beginning before the foundation of the Roman republic. ${ }^{39}$ However, representational healing votives, after a long decline in popularity in Italy, had all but ceased to be dedicated at Italic sanctuaries by the time northern Gaul was annexed into the empire. ${ }^{40}$ Even so, scholars note striking similarities in the types of votives offered in Italic and Gallic contexts, which has recently led to attempts to reconcile the practice's onset in Gaul concurrent with waning popularity in Italy. Cazanove argues that even if these votive objects were no longer being produced in Italy in the first century B.C.E., many likely remained on display for sanctuary visitors to see. ${ }^{41}$ Hughes suggests the possibility that the practice was purposefully

\footnotetext{
${ }^{36}$ Rémy and Mathieu 2009, 49-54.

${ }^{37}$ Hemelrijk 2012, 486-87.

${ }^{38}$ Cazanove 2016, 213.

${ }^{39}$ Turfa 1994, 224; Oberhelman 2014.

${ }^{40}$ Schultz 2006, 100; Hughes 2017, 143.

${ }^{41}$ Cazanove 2017, 71 .
}

introduced to the Gauls by Roman colonizers: even if colonizers considered the practice to be outdated, perhaps they thought offering healing votives an acceptable alternative to indigenous understandings of the body that they perceived as too violent (namely, indigenous practices surrounding the severing and displaying of heads).$^{42}$ While the Gauls were likely influenced to practice healing religion in this manner by their Mediterranean neighbors, the practice took on a distinctly Gallic flavor in Roman Gaul.

Some scholars assert that a dedicator's gender cannot necessarily be assumed from the gender of the votive object. ${ }^{43}$ It is likely true that in some instances family members or friends dedicated a votive for a person not present. However, it is safe to assume that the vast majority of votives analyzed here were dedicated in person by the individual in need of healing. Two pieces of evidence support this assumption. First, most Gallo-Roman healing sanctuaries were connected to water, especially to springs known for their healing properties. The minerals in some springs produced such physical relief that they are still frequented as healing spas to this day. ${ }^{44}$ Therefore, an important part of seeking healing at a sanctuary likely involved physical contact with the water such as bathing; healing would not have occurred without an actual visit by the person in need of healing. The other important piece of evidence that individuals mostly dedicated representations of themselves is the underrepresentation of children in the Gallo-Roman healing votive assemblage. While 1,050 adult gendered healing votives are reported in published sources, only 76 infant and child votives are reported. If it were common for one person to offer votives on behalf of an entire family, we would expect to see many more children represented in the assemblage, on a par with the numbers of adult men and women represented.

This study includes votives representing isolated body parts, generally called anatomical votives (fig. 1),

\footnotetext{
${ }^{42}$ Hughes 2017, 144.

${ }^{43}$ See esp. Glinister $(2009,117)$ in the context of the EtruscoLatial-Campanian votive tradition.

${ }^{44}$ Individuals still visit, e.g., the thermal spa at Luxeuil-lesBains, named for the Romano-Celtic god Luxovius, to whom the ancient healing temple was dedicated (Derks 1998, 198). According to the spa's website, the curative water is particularly recommended for those suffering from circulation issues and inflammation (www.chainethermale.fr/luxeuil-les-bains).
} 

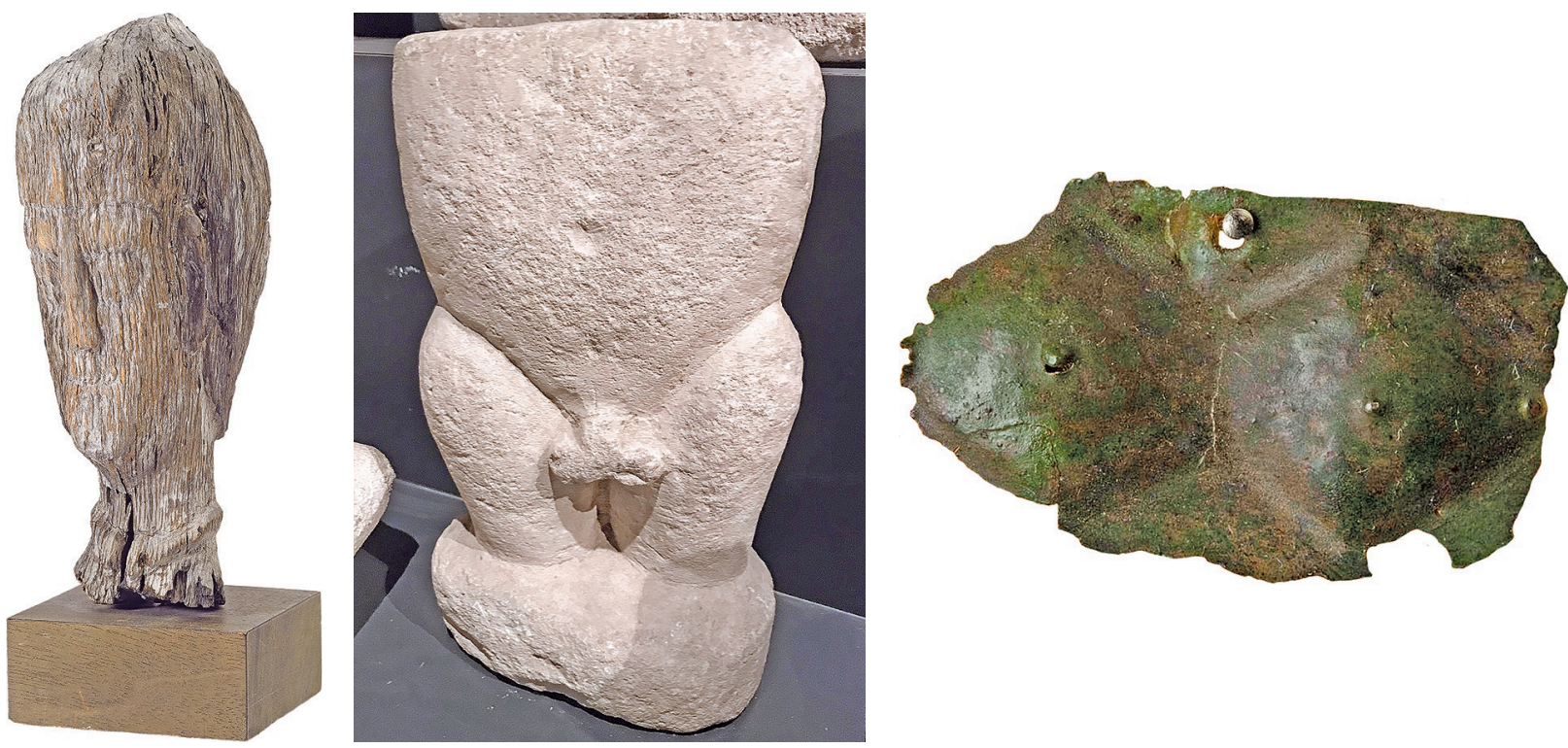

FIG. 1. Representational healing votives from Roman Gaul: left, man's head, wood, ht. $18.4 \mathrm{~cm}$, from Luxeuil-les-Bains. Besançon, Musée des Beaux Arts et d'Archéologie de Besançon, inv. no. 866.2.1 (C) Musée des Beaux Arts et d’Archéologie de Besançon - Photo GUENAT); center, man's torso, limestone, first-third century C.E., ht. $25 \mathrm{~cm}$, from Essarois. Châtillon-sur-Seine, Musée du Pays Châtillonais - Trésor de Vix; Espérandieu 1907-1955, 4:3433.6 (@ Nathalie Montenot); right, woman’s breasts, bronze, ht. $3 \mathrm{~cm}$, from Les Bolards. Nuits-Saint-Georges, Musée de Nuits-Saint-Georges, Stèles Gallo-Romaines, inv. no. 93.2.767/261 (courtesy Musée de Nuits-Saint-Georges; (C) Jean-Louis Bernuy).

as well as votives representing entire individuals. ${ }^{45} \mathrm{It}$ is conceivable that, unlike votives representing body parts, those representing entire individuals could have been votive deities, commonly offered at sanctuaries in Gaul, rather than healing votives. ${ }^{46}$ Votives of entire individuals were only included in this study if they were found in sanctuaries that scholars have identified as healing sanctuaries - that is, those connected to water sources ${ }^{47}$ those dedicated to a deity known to be a healer, ${ }^{48}$ or those at which caches of anatomical votives have been found. To avoid including deities

${ }^{45}$ While many votive body parts were originally formed as such, some votives catalogued as body parts appear to have broken off of more complete votive bodies. Fascinating symbolism accompanies both types of fragmented body. Hughes (2008) argues that dedicators may have offered individual votive body parts in Classical sanctuaries as a metaphor for discomfort with a sick or injured body. In addition, breakage of votives into constituent parts need not be seen as a result of postdepositional processes. Instead, Croxford (2003) argues, we should consider the possibility that votive objects were purposefully, ritually broken in antiquity.

${ }^{46}$ Talvas (2007) provides an impressive review of terracotta votives, many of which represented deities.

${ }^{47}$ Derks 1998, 196-98; Green 1999, 92.

${ }^{48}$ Green 1996a. in the data, every votive posited in the original publication of the object to represent a deity is excluded. Also excluded are figures depicted in a manner similar to representations of known deities. These include seated women, which could be images of an enthroned mother goddess, ${ }^{49}$ and figures riding horses, which could be depictions of the Gallic goddess Epona. ${ }^{50}$

While votives from 25 sites are included in this study (fig. 2, table 1), the size of the votive assemblage at some sites greatly exceeds that of others, to the extent that three sites-Chamalières, Sources de la Seine, and Forêt d'Halatte - account for $85.43 \%$ of all gendered votives examined here. These three sites also represent the range and diversity of the entire group of 25 sites. Chamalières (see fig. 2[4]), located just outside the ancient city of Civitas Arvernorum (modernday Clermont-Ferrand), was an open-air sanctuary with no permanent architecture. ${ }^{51}$ The sanctuary at Sources de la Seine (see fig. 2[23]), on the other hand, was made up of several buildings of Gallo-Roman style. This sanctuary was rural, about $20 \mathrm{~km}$ from the Gallic

\footnotetext{
${ }^{49}$ Bémont et al. 1993, 131; Dasen 1997, 126.

${ }^{50}$ Green 1986, 91-4.

${ }^{51}$ Romeuf 2000, 32.
} 


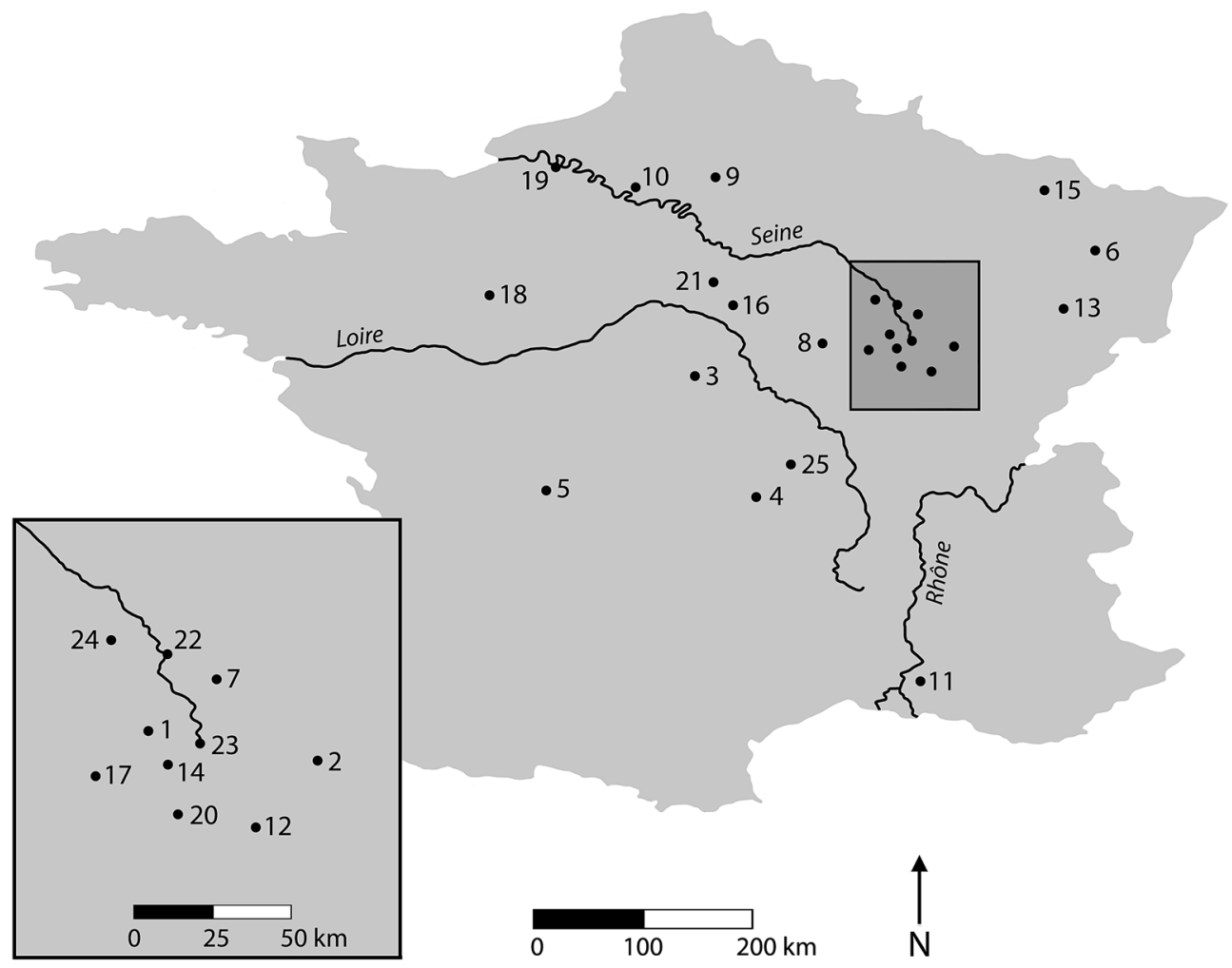

FIG. 2. Map based on modern France showing sanctuaries where gendered Gallo-Roman healing votives have been discovered. Numbers correspond to the sites listed in table 1 .

capital of Alesia. ${ }^{52}$ The sanctuary in the Forêt d'Halatte (see fig. 2[9]) falls between these two extremes: it includes a Gallic-style temple in an area enclosed by a sacred wall and is located a short distance from ancient Augustomagus. ${ }^{53}$

\section{GENDERED HEALING VOTIVES}

Most healing votives from Roman Gaul that have been published represent parts of the body that are not gendered (e.g., eyes, limbs, internal organs). My focus is on gendered votives, those for which gender determines physical differences (facial features, hairstyles, clothing, and sexual organs) (table 2)..$^{54}$ This includes representations of entire individuals, heads and busts,

\footnotetext{
${ }^{52}$ Green 1999, 4-6.

${ }^{53}$ Durand 2000, 98-102.

${ }^{54}$ Given varied excavation histories of these sites, the numbers of votives catalogued at each site should not be considered representative of the numbers of votives dedicated at those sites in antiquity. Instead, percentages (both of assemblages at individual sites and of the catalogue at large) provide a more accurate understanding of the dynamics of the practice.
}

and torsos. Fragments that can be determined to have originally been part of entire figures are considered entire individuals. Usually, these are votives for which the legs are partially preserved or the head has broken off. The category of heads and busts includes both votives originally meant to represent heads alone as well as heads broken from larger votives; it is impossible to know whether a broken-off head was originally part of an entire figure or a bust. The torso category includes representations of full torsos from the neck to the tops of the legs as well as breasts and genitals alone.

Gender-ambiguous votives, those of the gendered type that cannot be assigned a gender, are not included in this study (table 3). While some of these ambiguous votives cannot be assigned a gender because of breakage and wear, some are so schematic or highly stylized that the gender was likely ambiguous when they were created. Examples include incised stick figures on votive plaques or faces with lines to depict only the eyes and mouth (fig. 3 ). In these cases, it is difficult to know whether dedicators were offering ambiguously gendered representations of themselves and assuming that the deity would know their gender, or whether 
TABLE 1. Sites at which gendered votives have been discovered.

\begin{tabular}{|c|c|c|c|}
\hline & Site Name & $\begin{array}{c}\text { No. } \\
\text { Votives }\end{array}$ & References for Objects \\
\hline 1 & Alesia & 16 & Espérandieu 1907-1955, vols. 3, 9, 11 \\
\hline 2 & Beire-le-Châtel & 1 & Espérandieu 1907-1955, vol. 4 \\
\hline 3 & Bourges & 1 & Espérandieu 1907-1955, vol. 9 \\
\hline 4 & Chamalières & 379 & Romeuf 2000 \\
\hline 5 & Chassenon & 4 & Bémont et al. 1993 \\
\hline 6 & Deneuvre & 15 & Moitrieux 1992 \\
\hline 7 & Essarois & 53 & Espérandieu 1907-1955, vol. 4 \\
\hline 8 & Fontaines Salées & 1 & Espérandieu 1907-1955, vol. 14 \\
\hline 9 & Forêt d'Halatte & 136 & Durand and Finon 2000 \\
\hline 10 & Genainville & 4 & Fleury 1970; Mitard 1982 \\
\hline 11 & Glanum & 1 & Espérandieu 1907-1955, vol. 12 \\
\hline 12 & Les Bolards & 2 & Ministère de la Culture 2016 a \\
\hline 13 & Luxeuil-les-Bains & 10 & Espérandieu 1907-1955, vols. 7, 10 \\
\hline 14 & Massingy-lès-Vitteaux & 10 & Espérandieu 1907-1955, vol. 3 \\
\hline 15 & Metz & 1 & Espérandieu 1907-1955, vol. 5 \\
\hline 16 & Montbouy & 1 & Espérandieu 1907-1955, vol. 4 \\
\hline 17 & Montlay-en-Auxois & 5 & Dupont 1986 \\
\hline 18 & Perrières & 3 & Gruel et al. 2004 \\
\hline 19 & Saint-Ouen-de-Thouberville & 1 & Fauduet 1990 \\
\hline 20 & Sainte-Sabine & 5 & Espérandieu 1907-1955, vol. 3 \\
\hline 21 & Sceaux du Gâtinais & 1 & Roncin 1976 \\
\hline 22 & Source de la Douix & 10 & Coudrot 1997-1999; Buvot 1998 \\
\hline 23 & Sources de la Seine & 382 & Deyts 1983, 1994 \\
\hline 24 & Vertault & 4 & Espérandieu 1907-1955, vol. 4 \\
\hline 25 & Vichy & 4 & $\begin{array}{l}\text { Espérandieu 1907-1955, vol. 2; } \\
\text { Corrocher } 1982\end{array}$ \\
\hline
\end{tabular}

${ }^{a}$ Reference nos. M0144001874, M0144001882: www.pop.culture.gouv.fr/notice/joconde/ M0144001874; www.pop.culture.gouv.fr/notice/joconde/M0144001882.

they were offering purposefully ambiguous representations with the idea of not suggesting one gender or the other. ${ }^{55}$

The assemblage of healing votives from Roman Gaul shows striking diversity. Material preference differed within and between sites; at Chamalières, all healing votives were made in wood, while at Essarois

\footnotetext{
${ }^{55}$ For the possibility of purposeful gender ambiguity in Celtic art, see Green (1997, 899-905).
}

both stone and wood votives were dedicated. Stone, wood, and bronze were all commonly dedicated at Sources de la Seine, and even a limited number of terracotta votives were dedicated there as well. The size of individual votives also differed considerably within sites; the most striking range in votive height occurs at Chamalières, where wooden votives stand between 7 and $178 \mathrm{~cm}$ tall.

There were some common region-wide votive motifs. For example, the pilgrim with hooded cape, sometimes holding a hand out to present an offering, 
TABLE 2. Types of gendered votives.

\begin{tabular}{lccccc}
\hline & \multicolumn{2}{c}{ Women } & \multicolumn{3}{c}{ Men } \\
\hline Votive Type & No. & \% of Type & No. & \% of Type & Total No. \\
\hline Entire figures & 82 & 25.62 & 238 & 74.38 & 320 \\
Clothed & 78 & 27.86 & 202 & 72.14 & 280 \\
Unclothed & 4 & 21.05 & 15 & 78.95 & 19 \\
Clothing lifted & - & - & 21 & 100 & 21 \\
Heads and busts & 194 & 44.80 & 239 & 55.20 & 433 \\
Single heads & 188 & 44.66 & 233 & 55.34 & 421 \\
Multiple heads & 6 & 50.00 & 6 & 50.00 & 12 \\
Torsos & 133 & 44.78 & 164 & 55.22 & 297 \\
Clothed & 8 & 21.62 & 29 & 78.38 & 37 \\
Unclothed & 61 & 32.80 & 125 & 67.20 & 186 \\
Breasts & 60 & 100 & - & - & 60 \\
$\quad$ Individual breasts & 39 & 100 & - & - & 39 \\
$\quad$ Pairs/multiple & 21 & 100 & - & - & 21 \\
Genitals & 4 & 28.57 & 10 & 71.43 & 14 \\
\hline Total & 409 & & 641 & & 1,050 \\
\hline
\end{tabular}

TABLE 3. Gender-ambiguous votives.

\begin{tabular}{|c|c|c|c|}
\hline Votive Type & $\begin{array}{c}\text { No. } \\
\text { Ambiguous }\end{array}$ & $\begin{array}{c}\text { Total No. } \\
\text { of Type }\end{array}$ & $\begin{array}{c}\% \\
\text { Ambiguous } \\
\text { of Type }\end{array}$ \\
\hline Entire figures & 135 & 455 & 29.67 \\
\hline Heads and busts & 268 & 701 & 38.23 \\
\hline Torsos & 15 & 312 & 4.81 \\
\hline Total & 418 & 1,468 & \\
\hline
\end{tabular}

is common across sites. However, some motifs are particular to individual sites. This includes the man with clothing lifted to display his genitals, of which there are 19 examples at the Forêt d'Halatte but only two other examples in the rest of Gaul (one at the southern site of Glanum, and one possible example at Chamalières). One votive type unique to Chamalières is a statuette displaying the body from waist to feet, ${ }^{56}$ and Sources de la Seine and Sceaux-du-Gâtinais are the only sites where stylized torsos cut from bronze sheets have been found.

\footnotetext{
${ }^{56}$ Cazanove $(2017,72-3)$ notes the similarity of this form to Italic examples of healing votives.
}

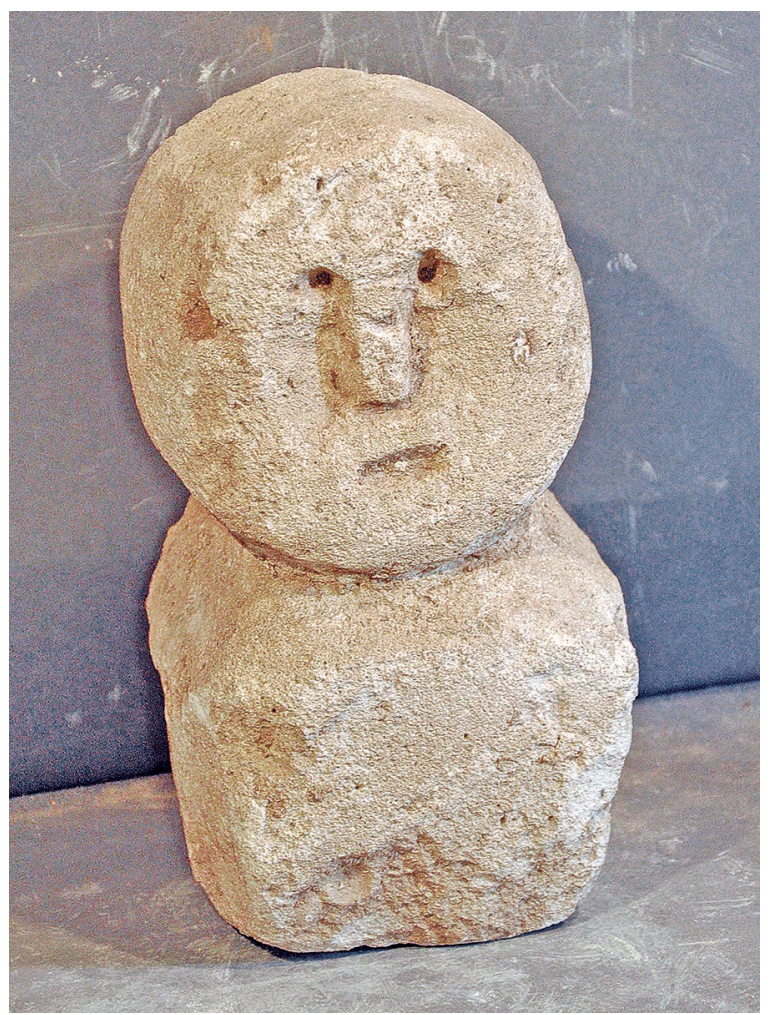

FIG. 3. Votive object of ambiguous gender, limestone, ht. 21.5 $\mathrm{cm}$, from Forêt d'Halatte. Senlis, Musée d'Art et d'Archéologie de Senlis, inv. no. A.00.5.32 (courtesy Musées de Senlis; (C) Musée d'Art et d'Archéologie de Senlis). 
These styles specific to individual sanctuaries suggest that the craftspeople who produced votives for particular sites produced similar votives in bulk to sell to sanctuary visitors. While it is apparent that, at some sanctuaries, those who purchased votives on-site had few styles to choose from, considerable diversity in votive styles does exist within many individual sanctuary assemblages. For example, votives offered at Sources de la Seine ranged from faces with eyes and mouth represented by incised lines to faces with highly stylized features to expertly rendered, detailed busts of individuals (fig. 4). It should be noted that diversity in style differentiates the healing votives in Roman Gaul from those in Republican-era Italy, where moldmade terracotta healing votives ensured that many dedicators would offer exact copies of the same votives. ${ }^{57}$ While terracotta votives were fairly common in Roman Gaul, only a very small number are catalogued as healing votives; and, unlike in republican Italy, no votive body parts (e.g., internal organs, eyes, genitals) were produced in terracotta. Instead, most Gallo-Roman terracotta votives represented deities and animals. ${ }^{58}$ One must wonder if there is a symbolic reason for the studious avoidance of mass production of terracotta healing votives in Gaul. Was the success of the prayer for healing perhaps contingent on the uniqueness of the votive?

\section{COMPARING WOMEN'S AND MEN'S DEDICATIONS}

While healing sanctuaries in Republican-period Italy were sometimes specialized for men's or women's health issues such that only (or mostly) men's or women's votives were present at a site, ${ }^{59}$ every site in Roman Gaul that has produced more than two gendered healing votives includes representations of both men's and women's bodies. There are nine sites in Gaul that have each produced 10 or more gendered votives, in varying proportions of women and men represented (table 4). Men and women were apparently drawn to individual healing sanctuaries at different rates, whether because of the convenience of the location or the healing specialties attributed to different deities. While the percentage of women's votives for the entire catalogue is $38.95 \%$, significantly less than the $50 \%$ we would ex-

\footnotetext{
${ }^{57}$ Dicus 2012, 86.

${ }^{58}$ Bémont et al. 1993, 141.

${ }^{59}$ Oberhelman 2014, 56-8.
}

pect to see if the votives offered matched the region's demographics, ${ }^{60}$ no Gallo-Roman healing sanctuary examined was a women-only or a men-only space. This lack of gendered segregation speaks to a culture in which gender was not a barrier to participation in ritual at healing sanctuaries.

The evidence shows that men and women dedicated healing votives in different ways. Because women and men are not equally represented in the votives overall, simply comparing the percentage of women's versus men's dedications for different categories is not useful. Instead, gendered percentages in each category must be compared to the percentages of women's and men's votives overall. Women's votives make up $38.95 \%$ of the dataset, so a proportion of women's votives that is statistically different from $38.95 \%$ diverges significantly from the expected value. If, for example, women offered $45 \%$ of a specific votive type, women are overrepresented in this category even though the proportion of women does not reach $50 \%$. If the proportions for each category differ from the expected proportion, then gender made a statistically significant impact on the type of votive an individual chose to dedicate. ${ }^{61}$

\section{Votive Material}

Careful comparison of the data shows that gendered differences existed in the choice of the material from which votives were made (namely, stone, wood, and bronze). These differences may be explained in two ways that are not necessarily mutually exclusive: as evidence of a chronological pattern or as evidence of different culturally motivated choices on the part of women and men.

A Chronological Explanation. One of the most complicating issues involved in studying this assemblage is the inability to date most votives securely. Even assigning a general date to a votive based on the age of

\footnotetext{
${ }^{60}$ An estimation that the population was composed of $50 \%$ men and 50\% women seems reasonable given the general difficulty in creating regional population statistics in the ancient world. In a highly militarized area, men might have noticeably outnumbered women. However, among the 25 sites represented in this study, the average distance from a military installation was $81.5 \mathrm{~km}$.

${ }^{61}$ The term "significant" denotes statistical significance, determined at a $95 \%$ confidence level $(p<0.05)$. Comparisons of percentages of the votive catalogue to the appropriate null hypothesis percentage are carried out using an exact binomial twosided single sample proportion test.
} 

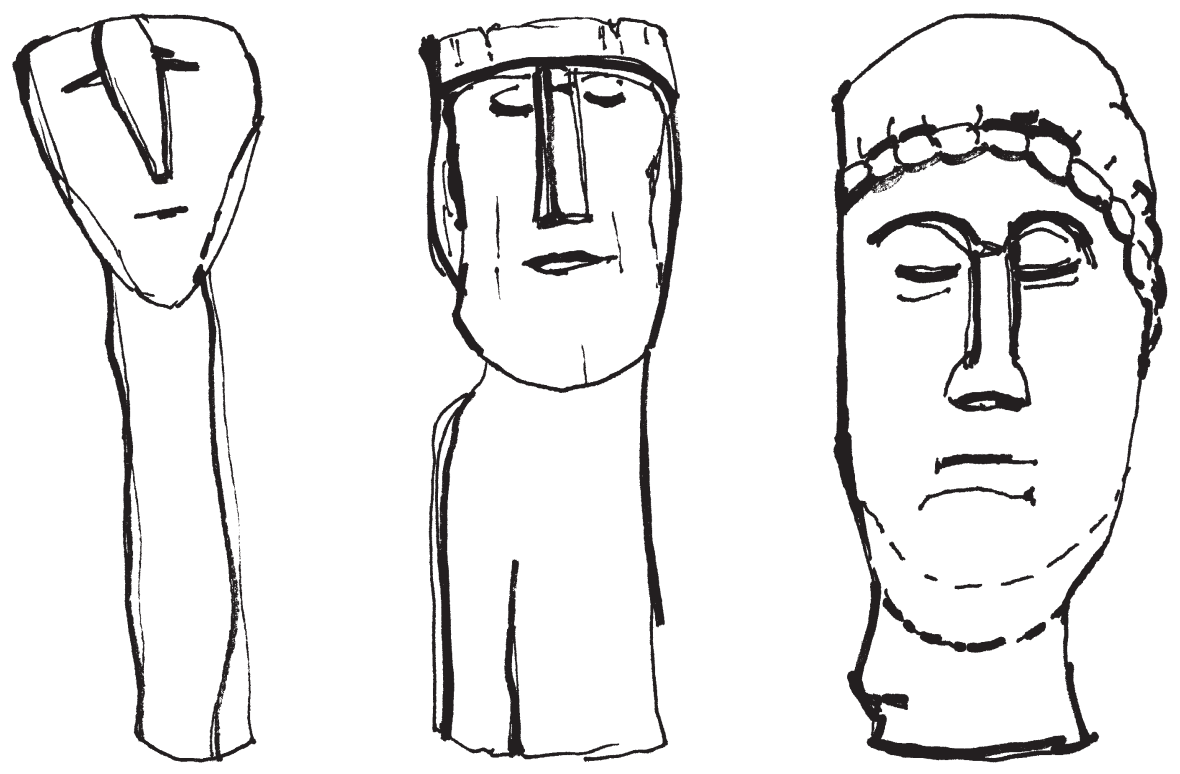

FIG. 4. Wooden votive heads of varying style found at Sources de la Seine, now Dijon, Musée Archéologique de Dijon: left, head of ambiguous gender, ht. $28 \mathrm{~cm}$, inv. no. 75.2.73; center, man's head, ht. $20 \mathrm{~cm}$, inv. no. 75.2.220; right, man's head, ht. $18.5 \mathrm{~cm}$, inv. no. 75.2.75 (drawings by D. Wigodner).

the sanctuary at which it was dedicated proves difficult because most sanctuaries were in use for hundreds of years. Therefore, the potential exists that the patterns identified are due to the periods in which the votives were dedicated rather than to differences between men's and women's practices. Because of this, any chronological patterns that can be identified are highly useful. The period in which wooden votives were offered provides one such pattern.

Seven sites in total have produced wooden healing votives in Roman Gaul. At Chamalières and Sources de la Seine, the two sites with the largest numbers preserved, relatively small date ranges can be assigned to the wooden votive assemblages. The deposit of wooden votives at Chamalières has been dated to a relatively brief period, from the end of the first century B.C.E. to about 70 C.E. ${ }^{62}$ At Sources de la Seine, dendrochronological analysis has shown that, while the sanctuary was in use from before the Roman period until the late fourth century C.E., the earliest wooden votives were produced ca. 40 B.C.E., and a majority date to before 50 C.E. ${ }^{63}$ While precise dates for the

\footnotetext{
${ }^{62}$ Romeuf 2000, 30.

${ }^{63}$ Green 1999, 9; Cazanove 2017, 68-9.
}

wooden votives at the other five sites are not available, the dates of the sanctuaries themselves (with the exception of the well at Coren, for which a terminus post quem does not exist) do support the possibility that wooden votives were dedicated in the first 100 to 150 years of Roman rule. The sanctuaries at Essarois and Luxeuil-les-Bains are both pre-Roman sanctuaries that continued in use into the Roman period. The sanctuary at Montbouy was in use from the early first century C.E., and the sanctuary at Montlay was in use beginning in the mid to late first century C.E. ${ }^{64}$

Based on study of the limited number of datable votive deposits at Gallic sanctuaries, Cazanove argues that while wooden healing votives began to be offered soon after Roman annexation of the northern region, bronze and stone votives began to be commonly offered only in the first century C.E. ${ }^{65}$ Given the

\footnotetext{
${ }^{64}$ See Audin $(1985,127)$ for Coren; Green $(1999,92-3)$ for Essarois; Derks $(1998,198)$ for Luxeuil-les-Bains; Bourgeois $(1992,177)$ for Montbuoy; and Dupont $(1986,57)$ for Montlay. Note that Coren is not among sites having produced gendered votives; it is included here only for the sake of completeness in reporting sites having produced wooden votives in the region of Gaul.

${ }^{65}$ Cazanove 2016, 219-20.
} 
TABLE 4. Sites with 10 or more gendered votives.

\begin{tabular}{lccccc}
\hline Site & $\begin{array}{c}\text { No. } \\
\text { Women }\end{array}$ & \% Women & No. Men & \% Men & Total No. \\
\hline Alesia & 13 & 81.25 & 3 & 18.75 & 16 \\
Chamalières & 127 & 33.51 & 252 & 66.49 & 379 \\
Deneuvre & 2 & 13.33 & 13 & 86.67 & 15 \\
Essarois & 35 & 66.04 & 18 & 33.96 & 53 \\
Forêt d'Halatte & 63 & 46.32 & 73 & 53.68 & 136 \\
Luxeuil-les-Bains & 4 & 40.00 & 6 & 60.00 & 10 \\
Massingy-lès-Vitteaux & 4 & 40.00 & 6 & 60.00 & 10 \\
Source de la Douix & 7 & 70.00 & 3 & 30.00 & 10 \\
Sources de la Seine & 134 & 35.08 & 248 & 64.92 & 382 \\
\hline
\end{tabular}

uncertainty of dating most votives, I base my analysis on an even more cautious connection between votive material and time period: while stone, terracotta, and metal votives may have been produced throughout the entire Roman period, wooden votives were only produced from the mid first century B.C.E. to about the late first century C.E. Therefore, comparing the assemblage of wooden votives to the assemblage of votives of other materials provides some information about early dedicatory practice compared to practices over the entire period.

While the percentage of women's wooden votives is $31.98 \%$ (table 5), the percentage of women's votives in the rest of the materials (stone, metal, and terracotta) combined is $45.69 \%$ (out of 534 nonwooden gendered votives, 244 are women's). Under the assumption that wooden votives came exclusively from the first approximately 150 years of Roman rule, the proportion of women participating in the practice during this early period was smaller than the proportion of women who participated over the entire period; women's participation compared to men's increased over time.

It is tempting to interpret the increase in women's participation in healing ritual over time as an indication that the shakeup to the status quo caused by Roman colonialism provided new opportunities for women's involvement in religious ritual. A case may certainly be made for this interpretation. Under Roman rule, druids, Celtic religious leaders, were banned on the pretense of stopping barbaric religious practice in Gaul. This forced removal of the druids from power likely served to contain revolt, since druids sometimes acted as resistance leaders during the period immediately following annexation. ${ }^{66}$ Druids were also, however, exclusive keepers of Celtic religious knowledge that was presumably lost from many communities when they were banned. Removal of the druids from power may have democratized religion in Gaul to a certain extent, providing opportunities for individuals to participate in ritual in new ways. ${ }^{67}$ Were this the case, the evidence shows that, while men's participation was strong from the start, women's participation increased more slowly.

Since the evidence examined here is limited to healing religion, however, women's increased participation may not indicate newfound freedom and opportunity for them. In many societies, women's participation in healing religion is a sign not of women's equality but of their position in the domestic sphere. Women's participation in ritual meant to keep their families safe and healthy may be seen as an extension of family caregiving activities understood as the domain of women. In fact, there is evidence that women embrace ways to participate in ritual on behalf of the family because this ritual provides them with reasons to move

\footnotetext{
${ }^{66}$ Rankin 1996, 289-90; Webster 1997, 167-69.

${ }^{67}$ While both Celtic and classical sources make clear that women held formal roles in Celtic religious practice, it is not clear whether women could be druids (Thompson 1996, 8993; Hutton 2009, 43-4). In any case, a democratization of religion in Gaul may have affected men and women differently.
} 
TABLE 5. Votive material by gender.

\begin{tabular}{lcccccc}
\hline & & $\begin{array}{c}\text { Other } \\
\text { Betal }\end{array}$ & Stone & Terracotta & Wood & Total \\
\hline Women & 35 & 1 & 206 & 2 & 165 & 409 \\
Men & 94 & 0 & 191 & 5 & 351 & 641 \\
\% Women & 27.13 & 100.00 & 51.89 & 28.57 & 31.98 & 38.95 \\
\hline
\end{tabular}

more readily in public spaces and to form supportive communities with other women. ${ }^{68}$ When this is the case, a woman's body becomes, as Morrison argues, "a metonymy for a healthy functioning family." ${ }^{\circ}$ The abilities to conceive, to have successful pregnancies and births, and to nurse children become crucial for women to pursue through healing ritual for the good of their entire families.

Seen in this light, women's increasing participation over time in Gallo-Roman healing religion would be evidence of women's increased association over time with the domestic sphere and a stronger link between women's bodies and the well-being of their families. This would suggest that as Roman culture took hold more strongly, Gallic women-described as less restricted by gender roles before Roman annexationbegan to conform to more rigid Roman gender roles. However, women never became the primary seekers of healing. Women's participation in healing ritual may have reached parity with men's, but there is no evidence that during later Roman rule women dedicated votives more frequently than men did. The participation of women in any activity either much less often or much more often than men seems likely to signify gender inequality. In the data on healing votives, we do not see a large discrepancy overall between men's and women's participation rates. Given women's lack of political rights during the period, ${ }^{70}$ we should not consider these participation rates as evidence for the equality of men and women in Roman Gaul. However,

${ }^{68}$ Dubisch $(1995,211-12)$ discusses this concept in her ethnographic study of pilgrimage in Greek Orthodox religion. Doumato $(2000,128)$ focuses on the connection between gender and healing in modern Islam but makes the case that this occurs cross-culturally in many orthodox religions. Finucane (1977, 148) finds statistical evidence to support this cross-cultural claim in his study of pilgrimage in medieval England. In records of miracles, women visited shrines to pray for healing more often than men did.

${ }^{69}$ Morrison 2000, 3.

${ }^{70}$ Rémy and Mathieu 2009, 49-50. it is evidence for changes in the behavior of women over the course of the colonial period.

A Cultural Explanation. Alternatively, it should be considered that it was not the period in which wooden votives were dedicated but in fact the wood itself that explains the gendered difference in proportions between wooden votives and all other votives. Proportions differ for men's and women's dedication of stone and bronze votives, the two other large material categories, as well. Women dedicated more than $50 \%$ of stone votives, significantly more than expected. ${ }^{71}$ In contrast, women dedicated bronze votives significantly less often than expected, with women comprising only about one quarter of bronze votives (see table 5). ${ }^{72}$ It is notable that one site, Sources de la Seine, produced all but 10 of the 129 gendered bronze votives in the catalogue and therefore this number may not be representative of the overall situation. However, gendered proportions from Sources de la Seine do closely mirror the overall gendered proportions for stone (the Sources de la Seine proportion is $49.29 \%$ women, compared to $51.89 \%$ overall) and wood ( $28.46 \%$ women, compared to $31.98 \%$ overall).

Potential cultural associations with wood, stone, and bronze may explain why women and men dedicated votives of different materials at different rates. I propose that wood and bronze both have pre-Roman Gallic cultural associations while stone was associated with Roman cultural influence. Just as rivers and other water sources held Celtic religious importance, so too did forests and groves: several classical authors mention sacred Celtic groves and woods, with religious activity being carried out in these spaces without the necessity of an actual temple. In fact, the Celtic word nemeton, meaning sacred grove, was sometimes used to refer to sanctuaries in general. ${ }^{73}$ In addition, temples

\footnotetext{
${ }^{71} p=2.272 \times 10^{-7}$

${ }^{72} p=0.006526$.

${ }^{73}$ Green 1986, 21-2.
} 
built at sanctuaries in pre-Roman Gaul were built from wood, while Roman control brought with it a shift from wooden to stone temple construction. ${ }^{74}$ Dedicating a wooden votive may have signified an indigenous identity or recalled a period before Roman influence.

Metal (especially bronze weapons and armor) was a common dedicatory material at Iron Age Gallic sanctuaries. ${ }^{75}$ In addition, much of the preserved preRoman Celtic art from Gaul takes the form of bronze sheets or bronze objects decorated in relief. ${ }^{76}$ Out of all catalogued Gallo-Roman healing votives, only 11 of 379 bronze votives are not in the form of an embossed sheet. Offering objects that recalled this Celtic artistic style may be seen as a means to express an indigenous identity (fig. 5). This discussion is not meant to suggest that use of wooden or bronze votives was exclusive to Celtic religious practice. However, offering a votive made of these materials may have been a means of expressing an indigenous Gallic identity.

Stone, on the other hand, was rarely used in art in Gaul before the Roman period. When it was, it tended to be in southern Gaul, long open to Mediterranean influence, not in the northern region where most healing sanctuaries were located. ${ }^{77}$ While animal bones, ceramics, and metal objects are all commonly found in ritual contexts in pre-Roman Gaul, stone objects and figures are not. ${ }^{78}$ In contrast, reliefs and statues made of stone were ubiquitous in Rome. It is reasonable to propose that stone, especially human representations in stone, would have been considered by those living in Roman Gaul to have a certain Roman flavor.

In this case, while women more often dedicated votives made from the Roman-associated material (stone), men more often dedicated with indigenousassociated materials (wood and bronze). This suggests that women were drawn to expressing a more culturally Roman identity and less interested in connecting themselves with indigenous symbolism than men were. At the same time, this difference may also provide another line of evidence for the theory proposed above that women's participation in healing religion increased over time. If we assume that Roman Gaul generally became more culturally Roman over time,

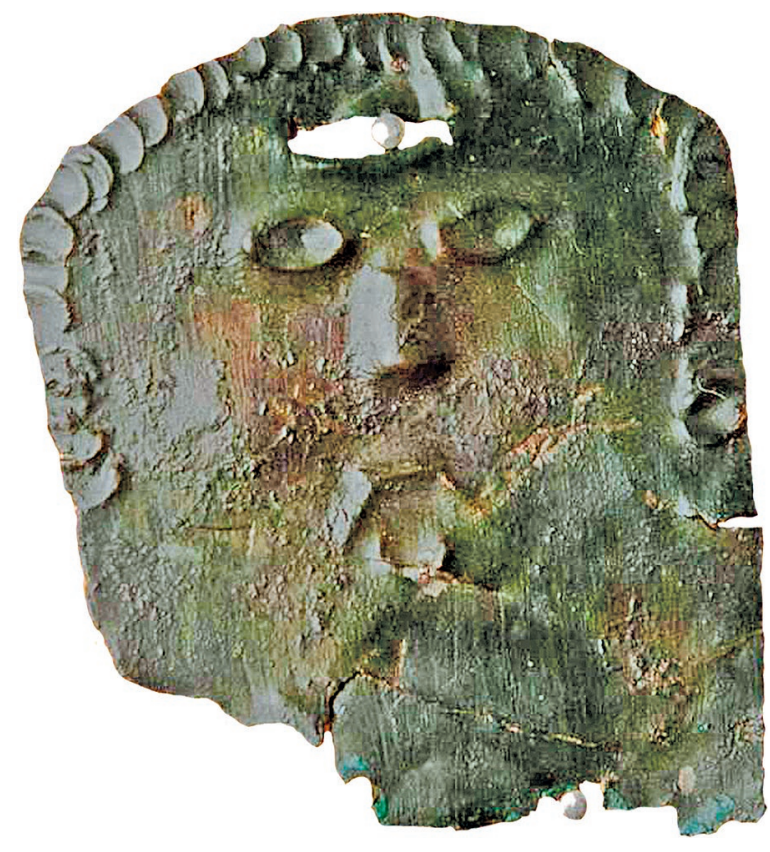

FIG. 5. Votive head, embossed bronze, ht. $4 \mathrm{~cm}$, found at Les Bolards. Nuits-Saint-Georges, Musée de Nuits-Saint-Georges, Stèles Gallo-Romaines, inv. no. 93.2.766/215 (courtesy Musée de Nuits-Saint-Georges; (C) Jean-Louis Bernuy).

women being better represented in the most culturally Roman medium suggests that women dedicated more often when stone had become more popular.

\section{Votive Type}

As described above, I have categorized gendered votive types into three main groups: entire figures, heads, and torsos. While women are significantly underrepresented in entire figures, ${ }^{79}$ they are slightly overrepresented in both heads ${ }^{80}$ and torsos. ${ }^{81}$ In addition, while entire figures and heads make up almost equal proportions of the entire assemblage of men's votives, torsos make up only about one quarter of men's votives. For women's votives, in contrast, heads make up the largest proportion, with torsos comprising the second largest proportion (table 6). These differences may suggest something about the types of physical issues men and women saw fit to address at healing sanctuaries. They may also relate to ease of access: it was easier for men to access healing sanctuaries to maintain general health

\footnotetext{
${ }^{74}$ Fauduet 1993, 69.

${ }^{75}$ Green 1986, 21.

${ }^{76}$ Laing and Laing 1992, 43; Green 1996b, 40-5.

${ }^{77}$ Finlay 1973, 66; Nerzic 1989, 8.

${ }^{78}$ Green 1986, 21.
} 
while women could more often only make the trip to address specific ailments.

Given women's heightened stake in fertility, childbirth, and nursing, the fact that torsos comprise a larger proportion of women's votives than men's votives is logical. It is somewhat surprising, therefore, that heads make up a much larger proportion of women's votives than torsos do. If offering a votive head was meant to treat some specific ailment of the head, women's overrepresentation in head votives may be due to a biological cause, such as the higher incidence of migraines in women than in men. ${ }^{82}$ The pattern also suggests that, despite the importance of fertility in the lives of women and their elevated responsibility for a successful pregnancy, women's health concerns were not at all limited to reproduction; it was not the issue they visited healing sanctuaries most often to address. Above, I discussed the way in which gender segregation and inequality in societies cause the health of women's bodies to be representative of the well-being of entire families. Biologically, there is an extent to which this must be true regardless of the level of equality between men and women. The evidence from the healing votives, however, suggests that in Roman Gaul a woman's body was not seen as solely or primarily the vehicle for her family's well-being, at least not by women themselves. Nonreproductive concerns were far more common than reproductive ones, especially considering that not all women's votive torsos are likely to have been connected to reproduction.

\section{Votive Style}

The most obvious aspect of diversity in these votive objects is their style. I assigned a style category to each object for which a photograph or drawing could be located, and which was well enough preserved to make a determination. The three categories are: stylized, semi-naturalistic, and naturalistic (fig. 6).

Stylized votives are those that seem to make no attempt at naturalism and therefore present the least Romanized depictions of individuals. These votives should not be thought of as simply made by unskilled artists (though this may well have been the case for some) but rather as representing an entirely different aesthetic. ${ }^{83}$ The most schematic votives (outlines, stick

\footnotetext{
${ }^{82}$ Stewart et al. 2008, 1174.

${ }^{83}$ Green 1986, 205. Johns (2003, 12-13) summarizes this argument as well, though she points out that we should not dis-
}

TABLE 6. General votive type by gender.

\begin{tabular}{lcccc}
\hline & $\begin{array}{c}\text { Entire } \\
\text { Figures }\end{array}$ & Heads & Torsos & Total \\
\hline Women & 82 & 194 & 133 & 409 \\
Men & 238 & 239 & 164 & 641 \\
\% Women & 25.62 & 44.80 & 44.78 & 38.95 \\
\hline
\end{tabular}

figures, or those entire figures that lack defined limbs) are easily categorized as stylized. Votives with more detail were categorized as stylized if they exhibited two or more of the following characteristics:

Decoration is simple geometric patterns including lines or dots.

Clothing is not defined or is represented by simple incised lines.

Body parts are abstracted into simple incised lines.

Hair is chunky or undetailed.

Body proportions are unrealistic.

The nose is triangular.

The mouth is formed by a slit.

The eyes are protruding, large, and almond-shaped (a feature of Celtic artistic style). ${ }^{84}$

The head is triangular, rectangular, or pear-shaped (a feature of Celtic artistic style). ${ }^{85}$

On the other end of the spectrum, naturalistic votives depict their subjects fairly accurately and realistically. These votives reflect the classic Greco-Roman artistic style. Facial features and body proportions are true to life, an attempt was made to show the true behavior of musculature and bone structure, and all features are plastically modeled, not incised; naturalism is especially evident in the folds of clothing.

The semi-naturalistic category is the largest one. These are votives that cannot be categorized as highly naturalistic in the style of Roman statuary but in which an obvious attempt at naturalism is present; the artist valued naturalism to a degree. These generally have relatively accurate body proportions and fairly detailed features, though details are often simplified (folds in clothing are often represented by incised lines, for example) and features may depict some stylization (such as almond-outlined eyes or stylized hair). This

\footnotetext{
regard differing levels of artistic skill in analyzing these objects.

${ }^{84}$ Finlay 1973, 66; Nerzic 1989, 8.

${ }^{85}$ Finlay 1973, 66; Nerzic 1989, 8.
} 

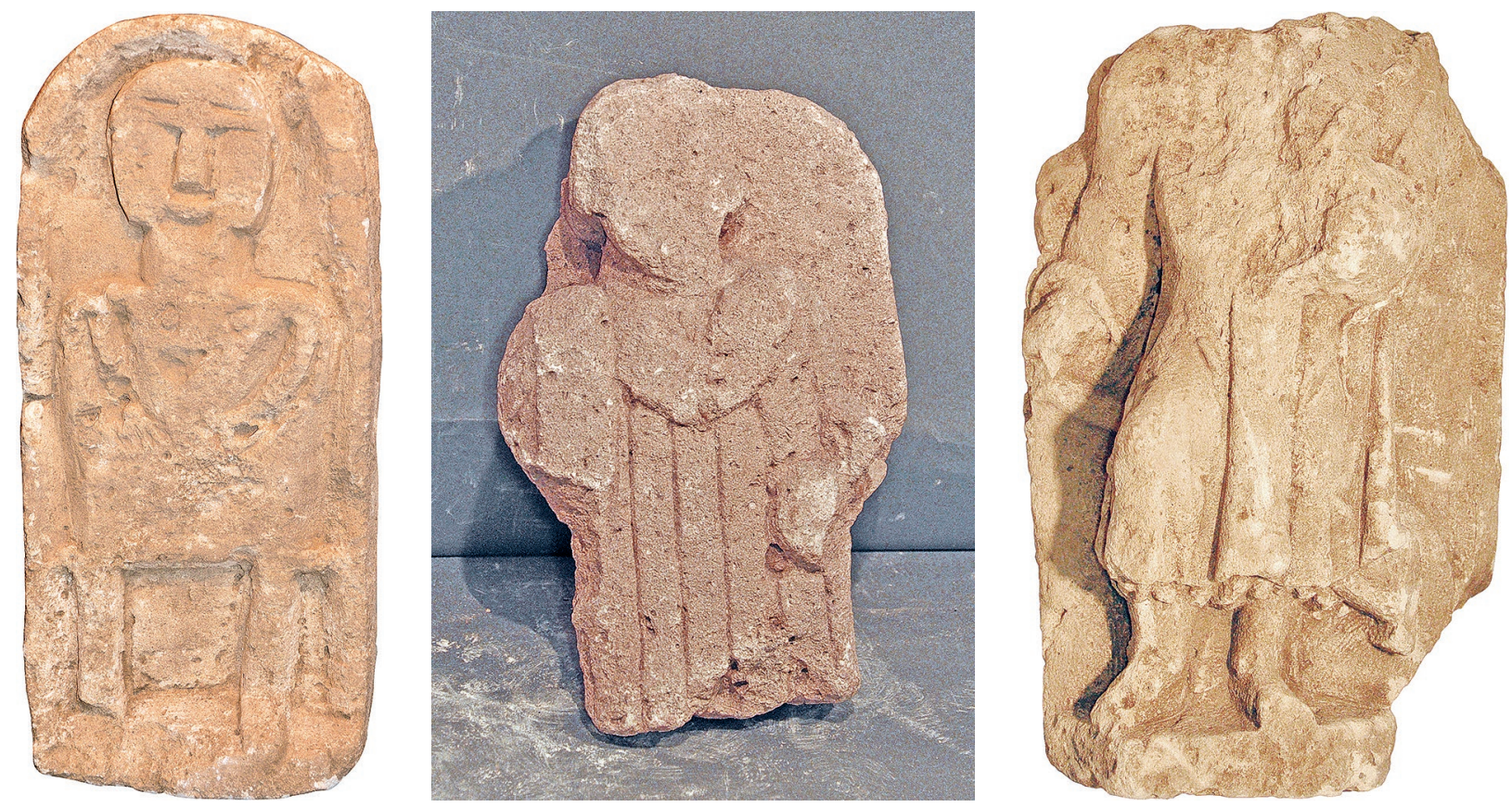

FIG. 6. Votives representing entire individuals in different artistic styles, all from Forêt d'Halatte. Senlis, Musée d'Art et d’Archéologie de Senlis: left, stylized votive, limestone, ht. $33 \mathrm{~cm}$, inv. no. A.99.3.01; center, semi-naturalistic votive, limestone, ht. $25.5 \mathrm{~cm}$, inv. no. A.00.5.73; right, naturalistic votive, limestone, ht. 40 cm, inv. no. A.97.4.1 (courtesy Musées de Senlis; (C) Musée d'Art et d'Archéologie de Senlis).

category includes those votives that are not totally stylized. The possibility should be considered that some individuals consciously chose to bridge Celtic and Roman artistic styles with their votives, perhaps to reflect a creolized identity. In order to include in this category purposefully creolized Gallo-Roman images, votives were categorized as semi-naturalistic if they depicted only one stylized feature.

While these categories simplify the diversity of styles displayed by the votives, it is clear that seminaturalistic and naturalistic votives fit easily into the Roman artistic style, while stylized votives very obviously do not and were not meant to. While some votives wear either obviously Roman or obviously indigenous clothing (such as the Gallic cape), accessories (such as the Celtic torque), or hairstyles, the ethnic association of clothing and accessories was not a factor in style determination. ${ }^{86}$

\footnotetext{
${ }^{86}$ It may be that some votive representations show important aspects of creolization, e.g., in depicting Celtic clothing or accessories in a highly naturalistic style, but analysis of this sort is outside of the scope of this study for two reasons. First, not all votives have the same chance of having these types of features
}

Individual sites show significant diversity in votive style, some of which is undoubtedly the result of chronological developments. If a sanctuary was in use for several hundred years, the styles of votives offered at the sanctuary must have changed over time. However, this diversity is not solely the result of chronological differences. The best evidence that different votive styles were offered concurrently is the assemblage of votives preserved at Chamalières, a sanctuary that was in use for less than a century. ${ }^{87}$ At this site, most votives fall into the semi-naturalistic category. However, several votives display purposefully stylized features. In addition, several worked tree branches, not very detailed but obviously carved to look anthropomorphic, were dedicated. This diversity within a fairly short time period suggests that individuals chose to offer votives

\footnotetext{
(a torso will not depict a hairstyle, a head will not depict clothing style, and some votives depict naked bodies). Second, for a categorization of clothing, jewelry, or hairstyle to be dependable, the level of detail must be quite high. In practice, this means that such an analysis could not be carried out on stylized votives, making any patterns that came out of the analysis incomplete.

${ }^{87}$ Romeuf 2000, 30.
} 
of different styles at the same sanctuaries during the same periods.

Only about three-quarters of gendered votives could be categorized by style; in some cases no adequate image of a votive is available, the preservation is poor, or the votive is very fragmentary. Nonetheless, working with the stylistically categorized examples, statistical analysis shows significant differences between women's and men's votives (table 7 ). While women are technically overrepresented in the naturalistic category of votives, the small sample size makes this overrepresentation statistically insignificant. There is also no significant difference between the observed and expected proportion of women's semi-naturalistic votives. However, women's underrepresentation in stylized votives is statistically significant. ${ }^{88}$ This underrepresentation suggests that men were more likely than women to offer either votives that were simply made (possibly less expensive or homemade) or votives that were meant to channel a less Roman, more indigenous style.

It may be expected that over time style preference trended away from stylized votives as Roman culture became more integrated into the landscape of Roman Gaul. If it is true (as I propose above) that women made up a larger proportion of the dedicators at healing sanctuaries over time, the only possible way to address the question of whether the difference in gendered proportions of stylized votives has more to do with the period in which they were dedicated or the gender of the dedicator is to examine the gendered breakdown of stylized votives by material. The percentage of women's stylized wooden votives (18.46\%) is significantly less than the percentage of women's wooden votives in general (31.98\%). ${ }^{89}$ The percentage of women's stylized nonwooden votives (35.89\%) is also significantly less than the overall percentage of women's nonwooden votives (45.69\%). ${ }^{90}$ Given the lack of secure dating for most votives, this is the best indication available that the underrepresentation of women in stylized votives is not due only to the period in which the votive was dedicated: both the votives from the early period of Roman rule (wooden votives) and those from the entire period (votives of all other

\footnotetext{
${ }^{88} p=0.01556$

${ }^{89} p=0.02287$.

${ }^{90} p=0.004377$.
}

TABLE 7. Votive style by gender.

\begin{tabular}{lcccc}
\hline & $\begin{array}{c}\text { Natural- } \\
\text { istic }\end{array}$ & $\begin{array}{c}\text { Semi- } \\
\text { naturalistic }\end{array}$ & Stylized & Total \\
\hline Women & 9 & 205 & 87 & 301 \\
Men & 7 & 304 & 187 & 498 \\
\% Women & 56.25 & 40.28 & 31.75 & 37.67 \\
\hline
\end{tabular}

materials) show an underrepresentation of women in stylized votives.

This pattern contributes a new line of evidence to the understanding achieved through examination of funerary monuments, indicating that, in the Roman northwest, women did not act as the sole guardians of indigenous ethnicity. The funerary monuments show that, in some regions, women's representations did become the means for their families to present distinctly non-Roman, indigenous identities while, along the British frontier and for families of high socioeconomic status, women's representations depicted a family's adoption of Roman values. ${ }^{91}$ However, the diversity of healing votives suggests that they were available to individuals of low socioeconomic status as well. In addition, offering an anonymous votive would not have been an efficient method for a family to publicly express an identity. Even so, men more often chose to guard indigenous ethnicity with their votives while women more often chose more Romanized votives, a pattern that further complicates our understanding of expressions of identity in this colonial context.

\section{GENDERED INDIGENEITY AND ROMAN-NESS}

Analysis shows that women and men did indeed offer different types of votives on average. I have presented the differences as a dichotomy between indigenous and Roman, with women more often than men expressing their identities in more Romanized ways. The reality is much more complex, but this simplified dichotomy does prove useful for comparison and interpretation.

Women's overrepresentation among more Romanized votives is evident in the materials used for votives; stone (the material traditionally associated with Roman sculpture) was overrepresented while bronze and wood (materials that may have had symbolic

\footnotetext{
${ }^{91}$ Hope 1997, 254-58; Rothe 2012, 239-42; Carroll 2013, 571-72.
} 
connection to pre-Roman culture) were underrepresented in women's votives. The opposite was true for men. In addition, men were more likely than women to offer stylized votives, those associated not with a Roman artistic style but with a more indigenous artistic style. Two interpretations explored above may explain this pattern; one is concerned with the period in which the votives were offered while the other involves a gendered difference in the identities that individuals chose to express.

We can reasonably expect that over time individuals in Roman Gaul began to express their identities in more Roman ways. ${ }^{92}$ An increase in women's participation in the practice of offering healing votives over time would mean that women's votives appeared more Roman on average. This chronological explanation is supported by the smaller percentage of women in wooden votives (likely produced in the first century and a half of Roman rule) than in the percentage of women in votives of all other materials (likely produced throughout the entire Roman period). If the observed pattern is a chronological one, it suggests that women's participation in healing religion trended towards parity with men's while Gaul was under Roman rule.

The second explanation explored above is that, without reference to the time period, women more often than men chose to express a more Romanized identity while men more often chose a more indigenous identity. This explanation may be interpreted as relating to socioeconomic status. In scholarship on the Roman empire, it is generally accepted that high socioeconomic status was associated with increased Romanization. Displaying expensive Roman goods was associated with status, and wealthy individuals received Roman educations and held Roman political positions. ${ }^{93}$ Viewed in this context, the patterns in the votive objects may suggest that on average the women who offered healing votives were of a higher socioeconomic status than the men who did so. The corollary would be that lower-status women had less access to the practice than lower-status men. This would be difficult to prove because it is not clear that poverty was a barrier to participation. Many votives were likely of relatively low cost, and individuals could also make

\footnotetext{
${ }^{92}$ Haselgrove and Scull 1992, 9; Woolf 1998.

${ }^{93}$ Woolf 1998, 67-76; Webster 2001.
}

their own. A journey to a distant sanctuary may have been impossible for people of lower economic status, but visiting a local sanctuary would not have been. However, the patterns could also mean that women of all socioeconomic statuses dedicated healing votives while men of high status participated infrequently; this was a practice engaged in by women in general and by men of lower status. In either case, these patterns would suggest that socioeconomic status affected the practices of men and women differently.

Of course, these explanations are based on a dichotomy between women as Romanizing and men as culturally indigenous that was not universal; both men and women chose to express their identities in diverse ways all along the spectrum from indigenous to Roman. Both gendered and gender-neutral interpretations for both Romanized and indigenous votives should therefore be explored.

The most obvious explanation for a decision to offer a votive in a Roman manner is that a person viewed herself or himself as Roman. A person who grew up surrounded by Roman culture, either in Rome or in Gaul, likely would have gravitated toward a Romanized representation with little thought. Other reasons for the decision to offer a more Romanized votive are more strategic. It is possible, for example, that a Romanized votive represented an aspiration to the high status and wealth associated with Roman culture. It is also worth noting that all of those dedicating a healing votive did so in order to achieve crucial practical results, usually health or fertility. Therefore, the reason an individual offered a more Romanized votive could have been because she or he believed the deity being worshiped at the sanctuary was more likely to fulfill a prayer if the dedication was more Romanized.

These interpretations could apply to men or women. But, because women were more likely than men to represent themselves in a Romanized manner, we should ask why a Romanized self-representation might have particularly appealed to women. In a colonial context like Roman Gaul, a certain amount of acquiescence to Roman power was expected. Perhaps, while men had greater opportunity to exhibit their Roman-ness through civic or other public roles, women, with fewer of these public opportunities, felt more pressure to conform to Roman ways through their votives. This explanation reflects the argument of Hope who, in interpreting the reason for a larger number of women's tombstones than men's along Britain's frontier, suggests 
that women more often than men felt like outsiders with more need to express publicly the identity of the Roman majority. ${ }^{94}$ However, one may wonder about the extent to which a woman expected a Romanized representation offered anonymously to make an impact on her public persona.

Some possible interpretations for offering a votive reflecting indigeneity mirror the interpretations for asserting Roman identity. For example, the most obvious explanation for choosing an indigenous votive is that one did not feel at all Roman. In Roman Gaul, it is likely that some individuals who spent their lives isolated from Roman influence simply did not consider representing themselves in a more Romanized manner. It is also possible that, at sanctuaries to indigenous deities, dedicators believed offering a more indigenousstyled votive was more likely to produce results.

Offering an indigenous-styled votive could have been a small but purposeful form of active resistance to Roman rule. A history of organized revolts in Roman Gaul proves that deep discontent with Roman control existed (and was justified given the brutal conquest Gaul was subjected to), ${ }^{95}$ and assertion of a non-Roman individual identity seems an obvious choice for those not wishing to acquiesce to this powerful and violent colonizing force. ${ }^{96}$ Because colonial control necessarily requires exerting force on the indigenous body, rejection of that force through refusal to wear the colonizer's culture on the body either physically or in artistic representations is a powerful statement of resistance. ${ }^{97}$ Persons required to express a Romanized identity publicly as a result of their position in colonial society might have taken the opportunity while offering healing votives to express a safely anonymous indigenous identity. It seems likely that men, who held more official public roles, found themselves in this position more often than women.

\footnotetext{
${ }^{94}$ Hope 1997, 254-58.

${ }^{95}$ Dyson 1971, 242-50; Drinkwater 1983, 35-53; Woolf 1998, 29-34.

${ }^{96}$ See Hingley (1997), Jiménez (2008), and Ghisleni (2018) for examples of Roman scholars who argue that we should not view persistence of indigenous cultural forms and styles as evidence of inertia. Instead, material culture reflecting indigeneity may take on new meanings in Roman colonial contexts.

${ }^{97}$ Buckridge 1998; Lynn 2004; Loren 2008; Robb 2008.
}

\section{CONCLUSIONS}

As my analysis makes clear, women and men shared healing sanctuary spaces. In addition, women's and men's levels of participation in offering healing votives may have become more equal over time, and women's healing prayers were by no means limited to reproductive health. None of these observations suggests that women's rights or opportunities were limited as a result of the imposition of Roman culture, even though the limited historical and archaeological evidence would suggest that gender roles were more fluid and women participated in a wider sphere of activity in pre-Roman Gaul than in Roman Italy. Perhaps being active participants in shaping the way culture changed under Roman rule allowed women the opportunity to increase their status or well-being in this colonial context. Most importantly, women more often chose to dedicate in a more Romanized manner than men. I have presented two explanations for the patterns observed in these data; one is chronological while the other emphasizes possible differences in status of men and women who dedicated votives. In reality, both are likely true to varying degrees. Nevertheless, useful conclusions may still be reached regarding gendered differences in experiences of colonialism.

First, women are represented less frequently than men in gendered healing votives, but they are not far underrepresented. Women are also not overrepresented. Overrepresentation tends to occur in gendersegregated societies where women use participation in healing religion as a way to move more readily through the public sphere and to gather with other women. ${ }^{98}$ Overrepresentation in this case also would have been evidence that women's bodies became symbolic of the health of their entire families, problematic for women's status because it tends to reduce women to their reproductive role. ${ }^{99}$ If, as is likely, a chronological pattern did exist, the trend was towards parity in men's and women's participation. This may mean that over time the general socioeconomic conditions of the population improved to the extent that opportunities for poor women increased to the level of opportunities for poor men; both men and women of low socioeconomic status became more able to purchase healing votives or travel to sanctuaries.

\footnotetext{
${ }^{98}$ Dubisch 1995, 211-12; Doumato 2000, 128.

${ }^{99}$ Morrison 2000, 3.
} 
Regardless of the role chronology played in votive dedications, we can certainly conclude that women are not represented more often than men as indigenous. This study adds to recent work that has questioned the dichotomy between women as guardians of indigenous ethnicity and men as public participants in the colonizing culture. Women's votives, like men's, were quite diverse; they represented a variety of individual identities and reactions to colonial control. Nevertheless, when women dedicated healing votives, more often than not they chose to project a Roman identity-a powerful choice indeed.

Alena Wigodner

School of Anthropology

University of Arizona

P.O. Box 210030

Tucson, Arizona 85721

awigodner@email.arizona.edu

\section{Works Cited}

Amussen, S.D., and A.M. Poska. 2012. "Restoring Miranda: Gender and the Limits of European Patriarchy in the Early Modern Atlantic World." Journal of Global History 7:342-63.

Arnold, B. 1999. “'Drinking the Feast': Alcohol and the Legitimation of Power in Celtic Europe." CAJ 9(1):71-93.

Audin, P. 1985. "Les Eaux Chez les Arvernes et les Bituriges.” In La médecine en Gaule: Villes d'eaux, sanctuaires des eaux, edited by A. Pelletier, 121-44. Paris: Picard.

Beaudoin, M.A. 2014. "The Process of Hybridization Among the Labrador Métis." In Rethinking Colonial Pasts Through Archaeology, edited by N. Ferris, R. Harrison, and M.V.Wilcox, 315-32. Oxford: Oxford University Press.

Bémont, C., M. Rouvier-Jeanlin, and C. Lahanier, eds. 1993. Les figurines en terre cuite gallo-romaines. DAF 38. Paris: Editions de la Maison des Sciences de l'Homme.

Bittarello, M.B. 2009. "The Construction of Etruscan 'Otherness' in Latin Literature." GaR 56(2):211-33.

Bourgeois, C. 1992. Divona. Vol. 2, Monuments et sanctuaires du culte gallo-romain de l'eau. Paris: De Boccard.

Brumfiel, E.M. 2007. "Methods in Feminist and Gender Archaeology: A Feeling for Difference-and Likeness." In Women in Antiquity: Theoretical Approaches to Gender and Archaeology, edited by S.M. Nelson, 1-28. Lanham, Md.: AltaMira Press.

Buckridge, S.O. 1998. “'Dem Caa Dress Yah!’ Dress as Resistance and Accommodation Among Jamaican Women from Slavery to Freedom, 1760-1890." Ph.D. diss., Ohio State University.

Buvot, P. 1998. "La Source de la Douix à Châtillon-sur-Seine.” Archéologia 344:26-33.

Carroll, M. 2013. "Ethnicity and Gender in Roman Funerary Commemoration." In The Oxford Handbook of the
Archaeology of Death and Burial, edited by L.N. Stutz and S. Tarlow, 559-79. New York: Oxford University Press.

Cazanove, O. de. 2016. "Les offrandes anatomiques dans les lieux de culte du monde romain: Une histoire longue, de l'Italie à la Gaule, de la république à l'empire." Bulletin de la société des sciences historiques et naturelles de Semur-enAuxois et des fouilles d'Alésia 124:211-24.

-2017. "Anatomical Votives (and Swaddled Babies): From Republican Italy to Roman Gaul." In Bodies of Evidence: Ancient Anatomical Votives Past, Present and Future, edited by J. Draycott and E.J. Graham, 63-76. New York: Routledge.

Clavel-Lévêque, M. 1996. “Codage, norme, marginalité, exclusion: Le guerrier, la pleureuse et la forte femme dans la Barbarie gauloise." Dialogues d'Histoire Ancienne 22(1):223-51.

Coleman, M. 2015. "Gaulish Multilingualism? Writing, Receipts, and Colonial Engagement." Critical Multilingualism Studies 3(1):26-45.

Corrocher, J. 1982. "Les eaux thermales de Vichy dans l'antiquité." Revue Archéologique du Centre de la France 21(2):131-144.

Coudrot, J. 1997-1999. "La Douix de Châtillon-sur-Seine: Etat des recherches." Mémoires de la Commission des Antiquités de la Côte-d'Or 38:77-87.

Croxford, B. 2003. "Iconoclasm in Roman Britain?" Britannia 34:81-95.

Cunliffe, B. 1997. The Ancient Celts. New York: Oxford University Press.

Dasen, V. 1997. “A propos de deux fragments de Deae Nutrices à Avenches: Déesses-Mères et jumeaux dans le monde italique et gallo-romain." Bulletin de l'Association pro Aventico 39:125-40.

Deagan, K.A. 1983. Spanish St. Augustine: The Archaeology of a Colonial Creole Community. New York: Academic Press.

Derks, T. 1998. Gods, Temples and Ritual Practices: The Transformation of Religious Ideas and Values in Roman Gaul. Amsterdam: Amsterdam University Press.

Deyts, S. 1983. Les bois sculptés des Sources de la Seine. Gallia Suppl. 42. Paris: Editions du Centre National de la Recherche Scientifique.

-1994. Un peuple de pélerins: Offrandes de pierre et de bronze des Sources de la Seine. RAEst Suppl. 13. Dijon: Revue Archéologique de l'Est et du Centre-Est.

Dicus, K.D. 2012. "Actors and Agents in Ritual Behavior: The Sanctuary at Grasceta dei Cavallari as a Case-Study of the E-L-C Votive Tradition in Republican Italy." Ph.D. diss., University of Michigan.

Dietler, M. 2006. "Celticism, Celtitude, and Celticity: The Consumption of the Past in the Age of Globalization." In Celtes et gaulois dans l'histoire, l'historiographie et l'idéologie moderne. Actes de la Table Ronde de Leipzig, 16-17 Juin 2005, edited by S. Rieckhoff, 237-48. Glux-en-Glenne, France: Bibracte, Centre Archéologique Européen.

.2008. “'Our Ancestors the Gauls”: Archaeology, Ethnic Nationalism, and the Manipulation of Celtic Identity in Modern Europe." In Histories of Archaeology: A Reader in the History of Archaeology, edited by T. Murray and C. 
Evans, 194-221. New York: Oxford University Press. .2014. Archaeologies of Colonialism: Consumption, Entanglement, and Violence in Ancient Mediterranean France. Berkeley: University of California Press.

Dondin-Payre, M., and M. Raepsaet-Charlier, eds. 2006. Sanctuaires, pratiques cultuelles et territoires civiques dans l'occident romain. Brussels: Le Livre Timperman.

Doumato, E.A. 2000. Getting God's Ear: Women, Islam, and Healing in Saudi Arabia and the Gulf. New York: Columbia University Press.

Drinkwater, J.F. 1983. Roman Gaul: The Three Provinces, 58 $B C-A D$ 260. London: Croom Helm.

Dubisch, J. 1995. In a Different Place: Pilgrimage, Gender, and Politics at a Greek Island Shrine. Princeton: Princeton University Press.

Dupont, J. 1986. “Un sanctuaire de sources près de Saulieu en Morvan.” Archéologia 214:55-9.

Durand, M. 2000. "Le temple gallo-romain de la Forêt d'Halatte (Commune d'Ognon, Oise): Nouvelle interprétation du site à la suite des fouilles de 1996 à 1999.” Revue Archéologique de Picardie 18(1):93-142.

Durand, M., and C. Finon. 2000. "Catalogue des ex-voto anatomiques du temple gallo-romain de la Forêt d'Halatte (Oise)." Revue Archéologique de Picardie. No. spécial 18(1):9-91.

Dyson, S.L. 1971. "Native Revolts in the Roman Empire." Historia 20(2/3):239-74.

Espérandieu, E. 1907-1955. Recueil général des bas-reliefs de la Gaule romaine. 14 vols. Paris: Imprimerie Nationale.

Evans, T.L. 2004. Quantitative Identities: A Statistical Summary and Analysis of Iron Age Cemeteries in North-Eastern France 600-130 BC. Oxford: Archaeopress.

Fauduet, I. 1990. "Les ex-voto anatomiques du sanctuaire de Bû.” Revue Archéologique de l'Ouest 7(1):93-100.

1993. Les temples de tradition celtique en Gaule romaine. Paris: Editions Errance.

Ferris, Iain. 2003. Enemies of Rome: Barbarians Through Roman Eyes. Stroud, U.K.: The History Press.

Finlay, Ian. 1973. Celtic Art: An Introduction. Park Ridge, N.J.: Noyes Press.

Finucane, R.C. 1977. Miracles and Pilgrims: Popular Beliefs in Medieval England. London: Dent.

Fleury, M. 1970. "Circonscriptions de la région parisienne." Gallia 28(2):239-51.

Garman, A.G. 2008. The Cult of the Matronae in the Roman Rhineland: An Historical Evaluation of the Archaeological Evidence. Lewiston, N.Y.: Edwin Mellen Press.

Ghisleni, L. 2018. "Contingent Persistence: Continuity, Change, and Identity in the Romanization Debate." CurrAnthr 59(2):138-66.

Giddens, A. 1984. The Constitution of Society: Outline of the Theory of Structuration. Berkeley: University of California Press.

Glinister, F. 2009. "Burning Boats and Building Bridges: Women and Cult in Roman Colonisation." In Gender Identities in Italy in the First Millennium BC, edited by E. Herring and K. Lomas, 117-26. Oxford: BAR Publishing.

Green, M.J.A. 1986. The Gods of the Celts. Gloucester, U.K.: Alan Sutton. -1995a. Celtic Goddesses: Warriors, Virgins, and Mothers. London: British Museum Press.

- 1995b. "Introduction: Who Were the Celts?" In The Celtic World, edited by M.J.A. Green, 3-7. New York: Routledge.

- 1996a. "The Celtic Goddess as Healer." In The Concept of the Goddess, edited by S. Billington and M. Green, 26-40. New York: Routledge.

. 1996b. Celtic Art: Reading the Messages. London: Calmann \& King.

- 1997. "Images in Opposition: Polarity, Ambivalence and Liminality in Cult Representation." Antiquity 71(274):898-911.

-1999. Pilgrims in Stone: Stone Images from the GalloRoman Sanctuary of Fontes Sequanae. BAR-IS 754. Oxford: Archaeopress.

Greene, E. 2015. "Conubium cum Uxoribus: Wives and Children in the Roman Military Diplomas." JRA 28:125-59.

Gruel, K., V. Brouquier-Reddé, and F. Gury. 2004. "Le sanctuaire de Mars Mullo à Allonnes.” RA n.s. 1:209-14.

Harding, D.W. 2007. The Archaeology of Celtic Art. New York: Routledge.

Haselgrove, C.C., and C.J. Scull. 1992. "The Romanization and de-Romanization of Belgic Gaul: The Rural Settlement Evidence." In Current Research on the Romanization of the Western Provinces, edited by M. Wood and F. Queiroga, 9-24. BAR-IS S575. Oxford: Archaeopress.

Hemelrijk, E.A. 2012. "Public Roles for Women in the Cities of the Latin West." In A Companion to Women in the Ancient World, edited by S.L. James and S. Dillon, 478-90. Oxford: John Wiley \& Sons.

Hingley, R. 1997. "Resistance and Domination: Social Change in Roman Britain." In Dialogues in Roman Imperialism: Power, Discourse, and Discrepant Experience in the Roman Empire, edited by D.J. Mattingly, 81-102. JRA Suppl. 23. Portsmouth, R.I.: Journal of Roman Archaeology.

Holder, P.A. 1982. The Roman Army in Britain. New York: St. Martin's Press.

Hope, V.M. 1997. "Words and Pictures: The Interpretation of Romano-British Tombstones." Britannia 28:245-58.

Hughes, J. 2008. "Fragmentation as Metaphor in the Classical Healing Sanctuary." Social History of Medicine 21(2):217-36.

.2017. Votive Body Parts in Greek and Roman Religion. New York: Cambridge University Press.

Hutton, R. 2009. Blood and Mistletoe: The History of the Druids in Britain. New Haven: Yale University Press.

Jiménez, A. 2008. "A Critical Approach to the Concept of Resistance: New 'Traditional' Rituals and Objects in Funerary Contexts of Roman Baetica." In TRAC 2007: Proceedings of the Seventeenth Annual Theoretical Roman Archaeology Conference, London 2007, edited by C. Fenwick, M. Wiggins, and D. Wythe, 15-30. Oxford: Oxbow.

Johns, C. 2003. "Art, Romanisation, and Competence." In Roman Imperialism and Provincial Art, edited by S. Scott and J. Webster, 9-23. New York: Cambridge University Press.

Laing, L., and J. Laing. 1992. Art of the Celts. London: Thames and Hudson.

Lamoine, L. 2009. Le pouvoir local en Gaule romaine. 
Clermont-Ferrand, France: Presses Universitaires Blaise-Pascal.

Lewis, N. 1986. Greeks in Ptolemaic Egypt: Case Studies in the Social History of the Hellenistic World. Oxford: Clarendon Press.

Lightfoot, K.G. 2005. Indians, Missionaries, and Merchants: The Legacy of Colonial Encounters on the California Frontiers. Berkeley: University of California Press.

Lomas, K. 2014. "Ethnicity and Gender." In A Companion to Ethnicity in the Ancient Mediterranean, edited by J. McInerney, 483-96. Oxford: Wiley-Blackwell.

Lopez, D.C. 2007. "Before Your Very Eyes: Roman Imperial Ideology, Gender Constructs, and Paul's InterNationalism." In Mapping Gender in Ancient Religious Discourses, edited by T.C. Penner and C.V. Stichele, 11562. Boston: Brill.

Loren, D.D. 2008. In Contact: Bodies and Spaces in the Sixteenth- and Seventeenth-Century Eastern Woodlands. Lanham, Md.: Altamira Press.

Lynn, H.G. 2004. "Fashioning Modernity: Changing Meanings of Clothing in Colonial Korea." Journal of International and Area Studies 11(3):75-93.

Mata, K. 2013. "Colonial Entanglements and Cultic Heterogeneity on Rome's Germanic Frontier." In Ritual Failure: Archaeological Perspectives, edited by V.G. Koutrafouri, 131-54. Leiden: Sidestone Press.

Mattingly, D.J. 2011. Imperialism, Power, and Identity: Experiencing the Roman Empire. Princeton: Princeton University Press.

Ministère de la Culture. 2016. Collections des musées de France (Joconde). www.culture.gouv.fr/documentation/ joconde/fr.

Mitard, P. 1982. "La tête en tôle de bronze à Genainville (Vald'Oise)." Gallia 40(1):1-33.

Moitrieux, G. 1992. Hercules Salutaris: Hercule au sanctuaire de Deneuvre (Meurthe-et-Moselle). Nancy, France: Presses Universitaires de Nancy.

Morrison, S. 2000. Women Pilgrims in Late Medieval England. New York: Routledge.

Mullen, A. 2013. Southern Gaul and the Mediterranean: Multilingualism and Multiple Identities in the Iron Age and Roman Periods. New York: Cambridge University Press.

Nerzic, C. 1989. La sculpture en Gaule romaine. Paris: Editions Errance.

Oberhelman, S.M. 2014. "Anatomical Votive Reliefs as Evidence for Specialization at Healing Sanctuaries in the Ancient Mediterranean World." Athens Journal of Health $1(1): 47-62$.

Pollard, N. 2000. Soldiers, Cities, and Civilians in Roman Syria. Ann Arbor: University of Michigan Press.

Pope, R., and I. Ralston. 2011. "Approaching Sex and Status in Iron Age Britain with Reference to the Nearer Continent." In Atlantic Europe in the First Millennium BC: Crossing the Divide, edited by L. Armada and T. Moore, 375-414. Oxford: Oxford University Press.

Rankin, H.D. 1996. Celts and the Classical World. New York: Routledge.

Reddé, M. 2015. “Les capitales des cités gauloises, simulacra
Romae?" Gallia 72(1):1-17.

Redfern, R.C., M. Marshall, K. Eaton, and H.N. Poinar. 2017. “'Written in Bone': New Discoveries about the Lives and Burials of Four Roman Londoners." Britannia 48:253-77.

Rémy, B., and N. Mathieu. 2009. Les femmes en Gaule romaine: Ier siècle avant J-C-Ve siècle après J-C. Paris: Editions Errance.

Revell, L. 2008. Roman Imperialism and Local Identities. New York: Cambridge University Press.

Robb, J. 2008. "Meaningless Violence and the Lived Body: The Huron-Jesuit Collision of World Orders." In Past Bodies: Body-Centered Research in Archaeology, edited by D. Borić and J. Robb, 89-99. Oxford: Oxbow.

Romeuf, A. 2000. Les ex-voto gallo-romains de Chamalières (Puy-de-Dôme): Bois sculptés de la Source des Roches. Paris: Editions de la Maison des Sciences de l'Homme, Paris.

Roncin, M. 1976. "Un sanctuaire gallo-romain de la déesse Segeta à Sceaux-du-Gâtinais (Loiret).” Bulletin de la Société Archéologique et Historique de l'Orléanais 7(47):50-66.

Rothe, U. 2009. Dress and Cultural Identity in the Rhine-Moselle Region of the Roman Empire. BAR-IS 2038. Oxford: Archaeopress.

. 2012. “The 'Third Way': Treveran Women's Dress and the 'Gallic Ensemble.” AJA 116(2):235-52.

Rothschild, N.A. 2003. Colonial Encounters in a Native American Landscape: The Spanish and Dutch in North America. Washington, D.C.: Smithsonian Books.

Russell, P. 1995. An Introduction to the Celtic Languages. New York: Routledge.

Schultz, C.E. 2006. Women's Religious Activity in the Roman Republic. Chapel Hill, N.C.: The University of North Carolina Press.

Stewart, W.F., C. Wood, M.L. Reed, J. Roy, and R.B. Lipton. 2008. "Cumulative Lifetime Migraine Incidence in Women and Men." Cephalalgia 28(11):1170-78.

Talvas, S. 2007. "Recherches sur les figurines en terre cuite gallo-romaines en contexte archéologique.” Ph.D. diss., Université de Toulouse II le Mirail.

Tarble de Scaramelli, K. 2012. "Effects of Empire: Gendered Transformations on the Orinoco Frontier." In The Archaeology of Colonialism: Intimate Encounters and Sexual Effects, edited by B.L. Voss and E.C. Casella, 138-55. New York: Cambridge University Press.

Thompson, J.G. 1996. Women in Celtic Law and Culture. Lewiston, N.Y.: Edwin Mellen Press.

Trément, F. 2013. "Quel modèle de développement régional pour le Massif Central à l'epoque romaine?” In Les Arvernes et leurs voisins du Massif Central à l'epoque romaine: Une archéologie du développement des territoires. Vol. 2, edited by F. Trément, 315-42. Clermont-Ferrand, France: Revue d'Auvergne, Alliance Universitaire d'Auvergne.

Turfa, J.M. 1994. "Anatomical Votives and Italian Medical Traditions." In Murlo and the Etruscans: Art and Society in Ancient Etruria, edited by R.D. de Puma and J.P. Small, 224-40. Madison: University of Wisconsin Press.

Van Andringa, W. 2009. "Religions et integration des territoires de l'Europe occidentale à l'empire romain.” Pallas $80: 307-16$. 
Voss, B.L. 2005. "From Casta to Californio: Social Identity and the Archaeology of Culture Contact." American Anthropologist 107(3):461-74.

Webster, J. 1997. "A Negotiated Syncretism: Readings on the Development of Romano-Celtic Religion.” In Dialogues in Roman Imperialism: Power, Discourse, and Discrepant Experience in the Roman Empire, edited by D.J. Mattingly, 165-84. JRA Suppl. 23. Portsmouth, R.I.: Journal of Roman Archaeology.

2001. "Creolizing the Roman Provinces." AJA 105(2):209-25.

Wells, P.S. 1999. The Barbarians Speak: How the Conquered Peoples Shaped Roman Europe. Princeton: Princeton Uni- versity Press.

White, B.M. 1999. "The Woman Who Married a Beaver: Trade Patterns and Gender Roles in the Ojibwa Fur Trade." Ethnohistory 46(1):109-47.

Whittaker, C.R. 2004. Rome and Its Frontiers: The Dynamics of Empire. New York: Routledge.

Woolf, G. 1998. Becoming Roman: The Origins of Provincial Civilization in Gaul. New York: Cambridge University Press.

2011. Tales of the Barbarians: Ethnography and Empire in the Roman West. Malden, Mass.: Wiley-Blackwell.

Wyke, M. 2002. The Roman Mistress: Ancient and Modern Representations. New York: Oxford University Press. 